\title{
Helical Folding-Induced Stabilization of Ferromagnetic polyradicals based on triarylmethyl radical derivatives
}

\author{
Daniel Reta, Ibério de P. R. Moreira, Francesc Illas * \\ Departament de Química Física \& Institut de Química Teòrica i Computacional \\ (IQTCUB), Universitat de Barcelona, C/Martí i Franquès 1, 08028 Barcelona, Spain
}

Index of Supporting Information.

1. Primitive cell coordinates of optimized polymers structures for the ferromagnetic solution.

1.1. Linear conformation. Polymers 1a and 2a.

1.2. Helical conformation. Polymers $\mathbf{1 b}$ and $\mathbf{2 b}$.

2. Energy expressions, computed absolute energies and definition of magnetic solutions required for the extraction of magnetic exchange interactions.

2.1. Linear conformation. Polymers 1a and 2a

2.2. Helical conformation. Polymers $\mathbf{1 b}$ and $\mathbf{2 b}$.

3. Density of States and Band Structure diagrams for FM and AFM solutions of polymer $\mathbf{2 b}$.

4. Optimized geometries (high-spin solution) of the different decaradicals derived from polymers $\mathbf{1 b}$ and $\mathbf{2} \mathbf{b}$ and calculated energetic differences for the decaradical derived from polymer $\mathbf{2 b}$.

4.1. Optimized geometry of discrete helical decaradical derived from $\mathbf{1 b}$.

4.2. Optimized geometry of discrete helical decaradical derived from $\mathbf{2 b}$.

4.3. Calculated energetic differences in the helical decaradical derived from 2b

5. Singly occupied molecular orbitals (SOMO) and spin density for the helical decaradical derived from $\mathbf{2 b}$ 
Supporting Information

\section{Primitive cell coordinates of optimized polymers structures for the ferromagnetic solution.}

1.1. Linear polymers. Six magnetic centres per cell. Magnetic atoms 1-6.

Polymer 1a.

FINAL OPTIMIZED GEOMETRY - DIMENSIONALITY OF THE SYSTEM 1 (NON PERIODIC DIRECTION: LATTICE PARAMETER FORMALLY SET TO 500) **************************************************************************) LATTICE PARAMETERS (ANGSTROMS AND DEGREES) - BOHR $=0.5291772083$ ANGSTROM PRIMITIVE CELL

$\begin{array}{lllll}\text { A } & B & C & \text { ALPHA } & \text { BETA }\end{array}$

$29.62528651500 .00000000 \quad 500.00000000 \quad 90.00000090 .00000090 .000000$

$* * * * * * * * * * * * * * * * * * * * * * * * * * * * * * * * * * * * * * * * * * * * * * * * * * * * * * * * * * * * * * * * * * * * * * * * * * * * * * * * * * * * * * * * * * * * * * * * * *$

ATOMS IN THE ASYMMETRIC UNIT 72 - ATOMS IN THE UNIT CELL: 72 ATOM X/A Y(ANGSTROM) Z(ANGSTROM) 
$46 \mathrm{~T} \quad 1 \mathrm{H} \quad 3.422205014152 \mathrm{E}-01-1.164957656848 \mathrm{E}+00-2.404492733802 \mathrm{E}+00$ $\begin{array}{lllll}47 \mathrm{~T} & 1 \mathrm{H} & -1.577813065004 \mathrm{E}-01 & 1.165347590762 \mathrm{E}+00 & 2.404257960560 \mathrm{E}+00\end{array}$ $48 \mathrm{~T} \quad 1 \mathrm{H} \quad 1.755644651686 \mathrm{E}-01 \quad 1.499974924819 \mathrm{E}+00-2.211343836436 \mathrm{E}+00$ $49 \mathrm{~T} \quad 1 \mathrm{H} \quad 8.716356964523 \mathrm{E}-02-9.707188460855 \mathrm{E}-01 \quad 2.886205467381 \mathrm{E}-01$ $50 \mathrm{~T} \quad 1 \mathrm{H} \quad-4.128359848753 \mathrm{E}-01 \quad 9.706825507767 \mathrm{E}-01-2.889057660387 \mathrm{E}-01$ $\begin{array}{llllll}51 \mathrm{~T} & 1 \mathrm{H} & -2.461731010530 \mathrm{E}-01 & 2.359953205844 \mathrm{E}-01 & -9.844770095902 \mathrm{E}-01\end{array}$ $\begin{array}{llllll}52 \mathrm{~T} & 1 \mathrm{H} & 4.205097143279 \mathrm{E}-01 & 7.356159253623 \mathrm{E}-01 & 6.958313636354 \mathrm{E}-01\end{array}$ $53 \mathrm{~T} \quad 1 \mathrm{H} \quad-7.949092334649 \mathrm{E}-02-7.353770351203 \mathrm{E}-01-6.959590187839 \mathrm{E}-01$ $54 \mathrm{~T} \quad 1 \mathrm{H} \quad 2.538264969830 \mathrm{E}-01-2.361075923663 \mathrm{E}-01 \quad 9.844792941879 \mathrm{E}-01$

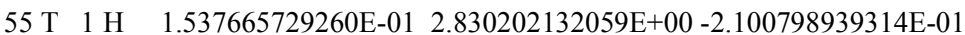
$\begin{array}{llllll}56 \mathrm{~T} & 1 \mathrm{H} & -3.462307070640 \mathrm{E}-01 & -2.830246569570 \mathrm{E}+00 & 2.095624237520 \mathrm{E}-01\end{array}$ $\begin{array}{lllll}57 \mathrm{~T} & 1 \mathrm{H} & -1.795583773963 \mathrm{E}-01 & -1.235039496291 \mathrm{E}+00 & 2.555292483117 \mathrm{E}+00\end{array}$ $58 \mathrm{~T} \quad 1 \mathrm{H} \quad 4.870908645652 \mathrm{E}-01-1.597217406475 \mathrm{E}+00-2.346464768782 \mathrm{E}+00$ $\begin{array}{llllll}59 \mathrm{~T} & 1 \mathrm{H} & -1.291173585678 \mathrm{E}-02 & 1.597747305000 \mathrm{E}+00 & 2.346128569031 \mathrm{E}+00\end{array}$ $60 \mathrm{~T} \quad 1 \mathrm{H} \quad 3.204408431199 \mathrm{E}-01 \quad 1.234811168379 \mathrm{E}+00-2.555338269351 \mathrm{E}+00$ $61 \mathrm{~T} \quad 1 \mathrm{H} \quad 7.941104669677 \mathrm{E}-02 \quad 3.979687246960 \mathrm{E}+00-1.003988206355 \mathrm{E}-01$

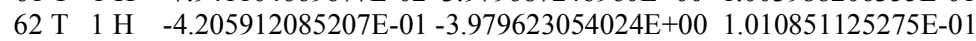
$\begin{array}{lllll}63 \mathrm{~T} & 1 \mathrm{H} & -2.539167139372 \mathrm{E}-01 & -1.904066400090 \mathrm{E}+00 & 3.496375876814 \mathrm{E}+00\end{array}$ $64 \mathrm{~T} \quad 1 \mathrm{H} \quad 4.127213856520 \mathrm{E}-01-2.077576464800 \mathrm{E}+00-3.396002512579 \mathrm{E}+00$ $\begin{array}{lllll}65 \mathrm{~T} & 1 \mathrm{H} & -8.727551027077 \mathrm{E}-02 & 2.077031666999 \mathrm{E}+00 & 3.396444400943 \mathrm{E}+00\end{array}$ $66 \mathrm{~T} \quad 1 \mathrm{H} \quad 2.460849452417 \mathrm{E}-01 \quad 1.904333855002 \mathrm{E}+00-3.496204254407 \mathrm{E}+00$ $67 \mathrm{~T} \quad 1 \mathrm{H} \quad 4.020895824069 \mathrm{E}-03-1.026904367853 \mathrm{E}+00-2.220005355590 \mathrm{E}-01$ $\begin{array}{llllll}68 \mathrm{~T} & 1 \mathrm{H} & -4.959795348387 \mathrm{E}-01 & 1.026828283984 \mathrm{E}+00 & 2.222176222845 \mathrm{E}-01\end{array}$ $69 \mathrm{~T} \quad 1 \mathrm{H} \quad-3.293073352934 \mathrm{E}-01 \quad 7.065255835118 \mathrm{E}-01-7.774520278378 \mathrm{E}-01$ $\begin{array}{lllll}70 \mathrm{~T} & 1 \mathrm{H} & 3.373615061694 \mathrm{E}-01 & 3.207684805218 \mathrm{E}-01 & 1.000650125840 \mathrm{E}+00\end{array}$ $71 \mathrm{~T} \quad 1 \mathrm{H} \quad-1.626384610862 \mathrm{E}-01-3.208031525058 \mathrm{E}-01-1.000584672934 \mathrm{E}+00$ $72 \mathrm{~T} \quad 1 \mathrm{H} \quad 1.706930739423 \mathrm{E}-01-7.064409038345 \mathrm{E}-01$ 7.776217413317E-01 $\mathrm{T}=$ ATOM BELONGING TO THE ASYMMETRIC UNIT

\section{Polymer 2a.}

FINAL OPTIMIZED GEOMETRY - DIMENSIONALITY OF THE SYSTEM 1 (NON PERIODIC DIRECTION: LATTICE PARAMETER FORMALLY SET TO 500)

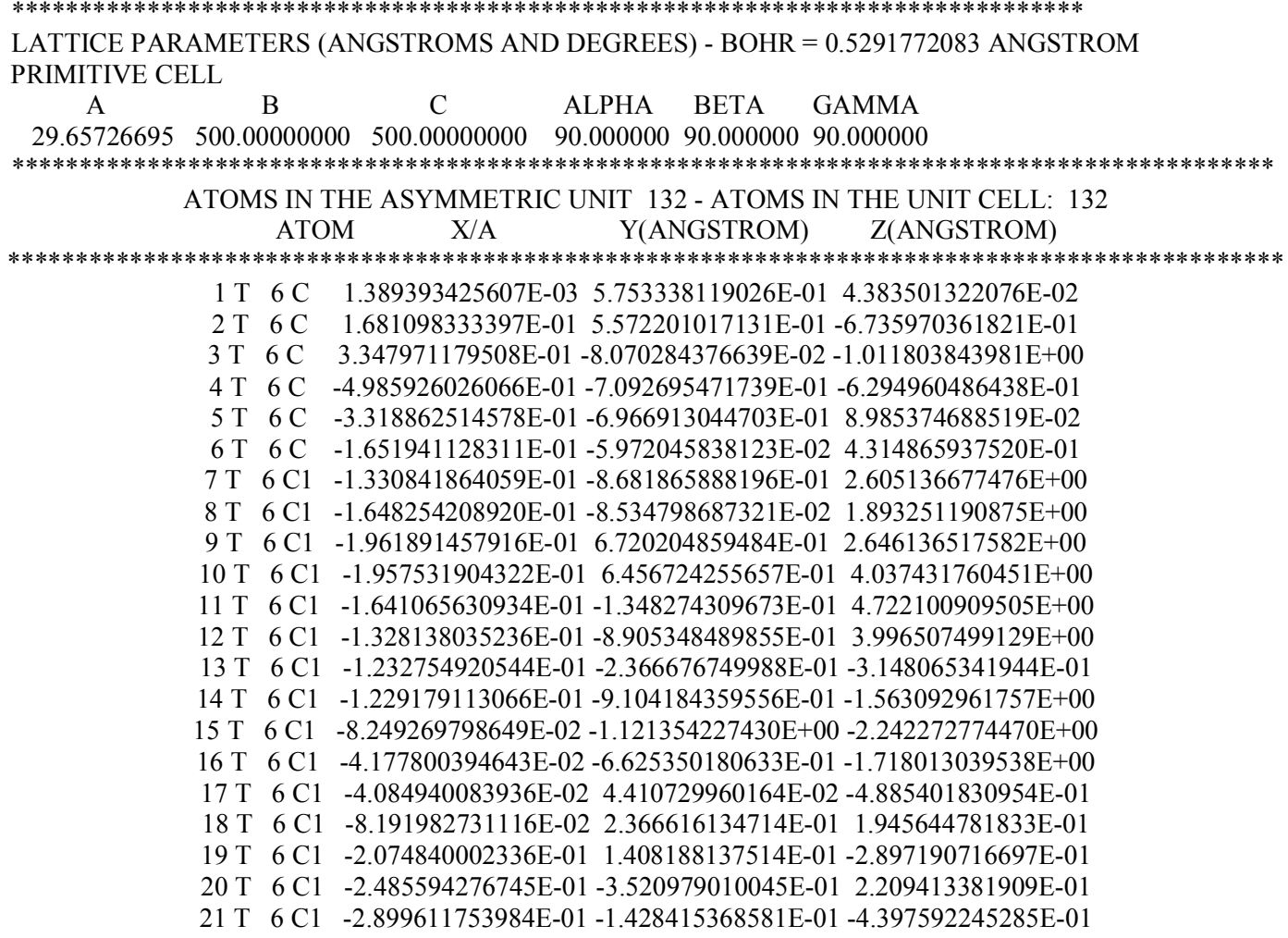


$22 \mathrm{~T} \quad 6 \mathrm{C} 1-2.896433029550 \mathrm{E}-01 \quad 6.031564230129 \mathrm{E}-01-1.646417300246 \mathrm{E}+00$

$23 \mathrm{~T} \quad 6 \mathrm{C} 1 \quad-2.492217174209 \mathrm{E}-01 \quad 1.083558765080 \mathrm{E}+00-2.171002435592 \mathrm{E}+00$ $24 \mathrm{~T} \quad 6 \mathrm{C} 1 \quad-2.084697608390 \mathrm{E}-01 \quad 8.548925955471 \mathrm{E}-01-1.515113927044 \mathrm{E}+00$ $25 \mathrm{~T} \quad 6 \mathrm{C} 1 \quad-3.316002769907 \mathrm{E}-01-1.974417579492 \mathrm{E}+00 \quad 8.005056002360 \mathrm{E}-01$ $26 \mathrm{~T} \quad 6 \mathrm{C} 1 \quad-3.629288998455 \mathrm{E}-01-2.242995736057 \mathrm{E}+00 \quad 1.834994605898 \mathrm{E}+00$ $27 \mathrm{~T} \quad 6 \mathrm{C} 1 \quad-3.625977937194 \mathrm{E}-01-3.460149766668 \mathrm{E}+00 \quad 2.509523014918 \mathrm{E}+00$ $28 \mathrm{~T} \quad 6 \mathrm{C} 1 \quad-3.310918945021 \mathrm{E}-01-4.447162177187 \mathrm{E}+00 \quad 2.175556742440 \mathrm{E}+00$ $29 \mathrm{~T} \quad 6 \mathrm{C} 1-2.998400926033 \mathrm{E}-01-4.201422892500 \mathrm{E}+00 \quad 1.156078651419 \mathrm{E}+00$ $30 \mathrm{~T} \quad 6 \mathrm{C} 1 \quad-3.000101135808 \mathrm{E}-01-2.986241680640 \mathrm{E}+00 \quad 4.779415771628 \mathrm{E}-01$ $31 \mathrm{~T} \quad 6 \mathrm{C} 1 \quad-3.741343824535 \mathrm{E}-01 \quad 3.094483424193 \mathrm{E}-02-9.597160596128 \mathrm{E}-02$ $32 \mathrm{~T} \quad 6 \mathrm{C} 1 \quad-4.152582866368 \mathrm{E}-01-6.554230001871 \mathrm{E}-01-2.662638572519 \mathrm{E}-01$ $33 \mathrm{~T} \quad 6 \mathrm{C} 1 \quad-4.566208938965 \mathrm{E}-01 \quad 2.371522086528 \mathrm{E}-02-4.151166854907 \mathrm{E}-01$ $34 \mathrm{~T} \quad 6 \mathrm{C} 1 \quad-4.562035856590 \mathrm{E}-01 \quad 1.441779008713 \mathrm{E}+00-3.729939637492 \mathrm{E}-01$ $35 \mathrm{~T} \quad 6 \mathrm{C} 1 \quad-4.157348919484 \mathrm{E}-01 \quad 2.133926272930 \mathrm{E}+00-2.198765040925 \mathrm{E}-01$ $36 \mathrm{~T} \quad 6 \mathrm{C} 1-3.750250053573 \mathrm{E}-01 \quad 1.449249542614 \mathrm{E}+00-9.047359303065 \mathrm{E}-02$ $37 \mathrm{~T} \quad 6 \mathrm{C} 1 \quad-4.984051421238 \mathrm{E}-01-1.965563115508 \mathrm{E}+00-1.377490548648 \mathrm{E}+00$ $38 \mathrm{~T} \quad 6 \mathrm{C} 1 \quad 4.701744243056 \mathrm{E}-01-2.992443656745 \mathrm{E}+00-1.089844551369 \mathrm{E}+00$ $39 \mathrm{~T} \quad 6 \mathrm{C} 1 \quad 4.704019495288 \mathrm{E}-01-4.187330208074 \mathrm{E}+00-1.803077160028 \mathrm{E}+00$ 40 T 6 C1 $-4.981149632298 \mathrm{E}-01-4.396920119735 \mathrm{E}+00-2.824381974444 \mathrm{E}+00$ $41 \mathrm{~T} \quad 6 \mathrm{C} 1-4.667800962584 \mathrm{E}-01-3.394340809690 \mathrm{E}+00-3.124447349507 \mathrm{E}+00$ $42 \mathrm{~T} \quad 6 \mathrm{C} 1 \quad-4.668399985269 \mathrm{E}-01-2.197427312682 \mathrm{E}+00-2.414503790079 \mathrm{E}+00$ 43 T 6 C1 $4.591716423153 \mathrm{E}-01-1.806100410234 \mathrm{E}-01-9.502166815921 \mathrm{E}-02$ $44 \mathrm{~T} \quad 6 \mathrm{C} 1 \quad 4.180851975184 \mathrm{E}-01-3.738649658439 \mathrm{E}-01-7.771940140198 \mathrm{E}-01$ $45 \mathrm{~T} \quad 6 \mathrm{C} 1 \quad 3.767211833080 \mathrm{E}-01 \quad 9.753997550012 \mathrm{E}-02-2.664496771727 \mathrm{E}-01$ $\begin{array}{llllll}46 \mathrm{~T} & 6 \mathrm{C} 1 & 3.770910146486 \mathrm{E}-01 & 7.702279714058 \mathrm{E}-01 & 9.825168589307 \mathrm{E}-01\end{array}$ $\begin{array}{lllll}47 \mathrm{~T} & 6 \mathrm{C} 1 \quad 4.175280112537 \mathrm{E}-01 & 9.816466956695 \mathrm{E}-01 & 1.660939973196 \mathrm{E}+00\end{array}$ $\begin{array}{lllllll}48 \mathrm{~T} & 6 \mathrm{C} 1 & 4.582455403910 \mathrm{E}-01 & 5.245295680684 \mathrm{E}-01 & 1.135453696285 \mathrm{E}+00\end{array}$ $49 \mathrm{~T} \quad 6 \mathrm{C} 1 \quad 3.351458380999 \mathrm{E}-01-5.747531432293 \mathrm{E}-02-2.473788961850 \mathrm{E}+00$ $50 \mathrm{~T} \quad 6 \mathrm{C} 1 \quad 3.038048332811 \mathrm{E}-01-8.174292014059 \mathrm{E}-01-3.224829082351 \mathrm{E}+00$ $51 \mathrm{~T} \quad 6 \mathrm{C} 1 \quad 3.042127892570 \mathrm{E}-01-7.933891264582 \mathrm{E}-01-4.616177628510 \mathrm{E}+00$ 52 T 6 C1 3.358119520391E-01 -1.269090095012E-02 -5.302581204010E+00 $53 \mathrm{~T} \quad 6 \mathrm{C} 1 \quad 3.670769135415 \mathrm{E}-01 \quad 7.457513043060 \mathrm{E}-01-4.578760138579 \mathrm{E}+00$ $54 \mathrm{~T} \quad 6 \mathrm{C} 1 \quad 3.668256956826 \mathrm{E}-01 \quad 7.258883342177 \mathrm{E}-01-3.187328178703 \mathrm{E}+00$ $55 \mathrm{~T} \quad 6 \mathrm{C} 1 \quad 2.925022179565 \mathrm{E}-01-2.798605460808 \mathrm{E}-01-2.904326624213 \mathrm{E}-01$ $\begin{array}{llllll}56 & \mathrm{~T} & 6 \mathrm{C} 1 & 2.514339010681 \mathrm{E}-01 & 2.120431592707 \mathrm{E}-01 & -8.026659933558 \mathrm{E}-01\end{array}$ $\begin{array}{llllll}57 \mathrm{~T} & 6 \mathrm{C} 1 & 2.100196760073 \mathrm{E}-01 & 4.304074691354 \mathrm{E}-03 & -1.421366888501 \mathrm{E}-01\end{array}$ $58 \mathrm{~T} \quad 6 \mathrm{C} 1 \quad 2.103199599627 \mathrm{E}-01-7.386927962497 \mathrm{E}-01 \quad 1.066404721146 \mathrm{E}+00$ $59 \mathrm{~T} \quad 6 \mathrm{C} 1 \quad 2.507307745334 \mathrm{E}-01-1.218332200852 \mathrm{E}+00 \quad 1.592354296352 \mathrm{E}+00$ $60 \mathrm{~T} \quad 6 \mathrm{C} 1 \quad 2.914939242274 \mathrm{E}-01-9.912943083692 \mathrm{E}-01 \quad 9.364948803264 \mathrm{E}-01$ $\begin{array}{lllll}61 \mathrm{~T} & 6 \mathrm{C} 1 & 1.684289374693 \mathrm{E}-01 & 1.832356700423 \mathrm{E}+00 & -1.389051920364 \mathrm{E}+00\end{array}$ $\begin{array}{lllll}62 \mathrm{~T} & 6 \mathrm{C} 1 & 1.371521608058 \mathrm{E}-01 & 2.096787641862 \mathrm{E}+00 & -2.425940974260 \mathrm{E}+00\end{array}$ $\begin{array}{llll}63 \mathrm{~T} & 6 \mathrm{C} 1 \quad 1.375128162367 \mathrm{E}-01 & 3.311334045414 \mathrm{E}+00 & -3.105173761475 \mathrm{E}+00\end{array}$ $64 \mathrm{~T} \quad 6 \mathrm{C} 1 \quad 1.690059992106 \mathrm{E}-01 \quad 4.299580729151 \mathrm{E}+00-2.773782573208 \mathrm{E}+00$ $65 \mathrm{~T} \quad 6 \mathrm{C} 1 \quad 2.002056854262 \mathrm{E}-01 \quad 4.057926684560 \mathrm{E}+00-1.751891482434 \mathrm{E}+00$ $\begin{array}{lllll}66 \mathrm{~T} & 6 \mathrm{C} 1 \quad 2.000043588909 \mathrm{E}-01 \quad 2.845386601575 \mathrm{E}+00-1.069058706140 \mathrm{E}+00\end{array}$ $67 \mathrm{~T} \quad 6 \mathrm{C} 1 \quad 1.258427622752 \mathrm{E}-01-1.689353900334 \mathrm{E}-01-4.860216002577 \mathrm{E}-01$ $68 \mathrm{~T} \quad 6 \mathrm{C} 1 \quad 8.473014281277 \mathrm{E}-02 \quad 5.189503049976 \mathrm{E}-01-3.192482170400 \mathrm{E}-01$ $69 \mathrm{~T} \quad 6 \mathrm{C} 1 \quad 4.334996540472 \mathrm{E}-02-1.587476370472 \mathrm{E}-01-1.680428048281 \mathrm{E}-01$ $70 \mathrm{~T} \quad 6 \mathrm{C} 1 \quad 4.373304195495 \mathrm{E}-02-1.576975407511 \mathrm{E}+00-2.054127520566 \mathrm{E}-01$ $71 \mathrm{~T} \quad 6 \mathrm{C} 1 \quad 8.418570518859 \mathrm{E}-02-2.270517152689 \mathrm{E}+00-3.557091667605 \mathrm{E}-01$ $72 \mathrm{~T} \quad 6 \mathrm{C} 1 \quad 1.249159433276 \mathrm{E}-01-1.587206175877 \mathrm{E}+00-4.867777927298 \mathrm{E}-01$ $\begin{array}{lllll}73 \mathrm{~T} & 1 \mathrm{H} & -4.877926126045 \mathrm{E}-01 & 1.979166497618 \mathrm{E}+00 & -4.886240174180 \mathrm{E}-01\end{array}$ $74 \mathrm{~T} \quad 1 \mathrm{H} \quad 1.212671067271 \mathrm{E}-02-2.113247156509 \mathrm{E}+00-8.860432555446 \mathrm{E}-02$ $\begin{array}{lllll}75 \mathrm{~T} & 1 \mathrm{H} & 1.786881526570 \mathrm{E}-01 & -9.047721106031 \mathrm{E}-01 & 1.588112466966 \mathrm{E}+00\end{array}$ $76 \mathrm{~T} \quad 1 \mathrm{H} \quad-1.545145205064 \mathrm{E}-01-1.282365555018 \mathrm{E}+00-1.967401573778 \mathrm{E}+00$ $\begin{array}{llllll}77 \mathrm{~T} & 1 \mathrm{H} & 3.454950374263 \mathrm{E}-01 & 1.140946848372 \mathrm{E}+00 & 1.387998836797 \mathrm{E}+00\end{array}$ $\begin{array}{lllll}78 \mathrm{~T} & 1 \mathrm{H} & -3.212704641142 \mathrm{E}-01 & 7.708481426833 \mathrm{E}-01 & -2.167885718957 \mathrm{E}+00\end{array}$ $79 \mathrm{~T} \quad 1 \mathrm{H} \quad-4.150652069972 \mathrm{E}-01-1.740348992010 \mathrm{E}+00-2.841696817459 \mathrm{E}-01$ $\begin{array}{lllll}80 \mathrm{~T} & 1 \mathrm{H} & 8.494801494612 \mathrm{E}-02 & 1.603925079455 \mathrm{E}+00 & -3.058824299734 \mathrm{E}-01\end{array}$

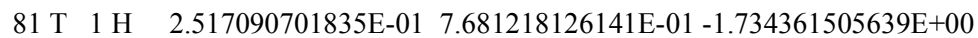
$82 \mathrm{~T} \quad 1 \mathrm{H} \quad-8.168770046474 \mathrm{E}-02 \quad 7.648802991664 \mathrm{E}-01 \quad 1.142384934165 \mathrm{E}+00$ $83 \mathrm{~T} \quad 1 \mathrm{H} \quad 4.183109931700 \mathrm{E}-01-9.010786856749 \mathrm{E}-01-1.725566441070 \mathrm{E}+00$ $84 \mathrm{~T} \quad 1 \mathrm{H} \quad-2.482992143383 \mathrm{E}-01-9.103616830990 \mathrm{E}-01 \quad 1.151356244152 \mathrm{E}+00$

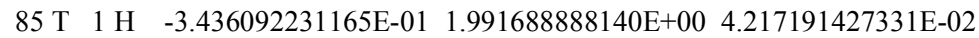
$86 \mathrm{~T} \quad 1 \mathrm{H} \quad 1.563210909700 \mathrm{E}-01-2.130790324696 \mathrm{E}+00-6.169573827076 \mathrm{E}-01$ $87 \mathrm{~T} \quad 1 \mathrm{H} \quad 3.228624762884 \mathrm{E}-01-1.378146469247 \mathrm{E}+00 \quad 1.342498025921 \mathrm{E}+00$ $88 \mathrm{~T} \quad 1 \mathrm{H} \quad-1.038947040154 \mathrm{E}-02-8.173790970398 \mathrm{E}-01-2.256022508506 \mathrm{E}+00$ 
$89 \mathrm{~T} \quad 1 \mathrm{H} \quad 4.896358751977 \mathrm{E}-01 \quad 6.793120428742 \mathrm{E}-01 \quad 1.673335732175 \mathrm{E}+00$ $90 \mathrm{~T} \quad 1 \mathrm{H} \quad-1.770921282177 \mathrm{E}-01 \quad 1.242492565437 \mathrm{E}+00-1.919765077538 \mathrm{E}+00$ $91 \mathrm{~T} \quad 1 \mathrm{H} \quad-4.159232349205 \mathrm{E}-01 \quad 3.221921130548 \mathrm{E}+00-2.016316502941 \mathrm{E}-01$ $92 \mathrm{~T} \quad 1 \mathrm{H} \quad 8.396815010550 \mathrm{E}-02-3.358541730895 \mathrm{E}+00-3.706715192770 \mathrm{E}-01$ $93 \mathrm{~T} \quad 1 \mathrm{H} \quad 2.504543903563 \mathrm{E}-01-1.776272792384 \mathrm{E}+00 \quad 2.526519199329 \mathrm{E}+00$ $94 \mathrm{~T} \quad 1 \mathrm{H} \quad-8.271769978026 \mathrm{E}-02-1.650966036636 \mathrm{E}+00-3.192802905595 \mathrm{E}+00$ $\begin{array}{llllll}95 \mathrm{~T} & 1 \mathrm{H} & 4.173078602131 \mathrm{E}-01 & 1.510118387629 \mathrm{E}+00 & 2.612107316557 \mathrm{E}+00\end{array}$ $96 \mathrm{~T} \quad 1 \mathrm{H} \quad-2.494822707212 \mathrm{E}-01 \quad 1.643402744495 \mathrm{E}+00-3.104043395481 \mathrm{E}+00$ $97 \mathrm{~T} \quad 6 \mathrm{C} 1 \quad 1.556714952632 \mathrm{E}-03 \quad 1.834430724695 \mathrm{E}+00 \quad 7.869367754240 \mathrm{E}-01$ $98 \mathrm{~T} \quad 1 \mathrm{H} \quad 1.129904041487 \mathrm{E}-01 \quad 1.326424346810 \mathrm{E}+00-2.695716677112 \mathrm{E}+00$

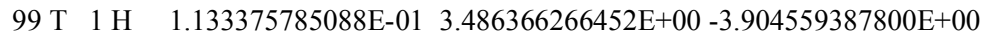
$100 \mathrm{~T} \quad 1 \mathrm{H} \quad 1.692264762292 \mathrm{E}-01 \quad 5.248075851711 \mathrm{E}+00-3.305987844575 \mathrm{E}+00$ $101 \mathrm{~T} \quad 1 \mathrm{H} \quad 2.246021338649 \mathrm{E}-01 \quad 4.823834458028 \mathrm{E}+00-1.480662206460 \mathrm{E}+00$

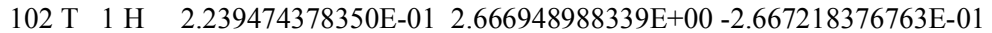
$103 \mathrm{~T} \quad 1 \mathrm{H} \quad 2.795523171790 \mathrm{E}-01-1.435701760974 \mathrm{E}+00-2.695469835561 \mathrm{E}+00$ $104 \mathrm{~T} \quad 1 \mathrm{H} \quad 2.799860172029 \mathrm{E}-01-1.393740079114 \mathrm{E}+00-5.170309695801 \mathrm{E}+00$ $105 \mathrm{~T} \quad 1 \mathrm{H} \quad 3.360691249940 \mathrm{E}-01 \quad 4.497218667176 \mathrm{E}-03-6.390045785981 \mathrm{E}+00$ $106 \mathrm{~T} \quad 1 \mathrm{H} \quad 3.915587921432 \mathrm{E}-01 \quad 1.363169521510 \mathrm{E}+00-5.103494466569 \mathrm{E}+00$ $107 \mathrm{~T} \quad 1 \mathrm{H} \quad 3.908136179040 \mathrm{E}-01 \quad 1.327243172434 \mathrm{E}+00-2.628723104497 \mathrm{E}+00$ $108 \mathrm{~T} \quad 1 \mathrm{H} \quad 4.460080321439 \mathrm{E}-01-2.838842183936 \mathrm{E}+00-2.882687851807 \mathrm{E}-01$ $109 \mathrm{~T} \quad 1 \mathrm{H} \quad 4.461212980210 \mathrm{E}-01-4.964593982916 \mathrm{E}+00-1.556185780444 \mathrm{E}+00$ $110 \mathrm{~T} \quad 1 \mathrm{H} \quad-4.980014511507 \mathrm{E}-01-5.331605885720 \mathrm{E}+00-3.380509473088 \mathrm{E}+00$ $111 \mathrm{~T} \quad 1 \mathrm{H} \quad-4.423962333472 \mathrm{E}-01-3.544211584277 \mathrm{E}+00-3.923349350017 \mathrm{E}+00$ $112 \mathrm{~T} \quad 1 \mathrm{H} \quad-4.427922513209 \mathrm{E}-01-1.415866677127 \mathrm{E}+00-2.659997695199 \mathrm{E}+00$ $113 \mathrm{~T} \quad 1 \mathrm{H} \quad-3.871100600420 \mathrm{E}-01-1.473796671539 \mathrm{E}+00 \quad 2.106670755165 \mathrm{E}+00$ $114 \mathrm{~T} \quad 1 \mathrm{H} \quad-3.868135579143 \mathrm{E}-01-3.638328400803 \mathrm{E}+00 \quad 3.307088171229 \mathrm{E}+00$ $115 \mathrm{~T} \quad 1 \mathrm{H} \quad-3.308969038274 \mathrm{E}-01-5.397756500337 \mathrm{E}+00 \quad 2.704026306807 \mathrm{E}+00$ $116 \mathrm{~T} \quad 1 \mathrm{H} \quad-2.754332453421 \mathrm{E}-01-4.966314451646 \mathrm{E}+00 \quad 8.828304586096 \mathrm{E}-01$ $117 \mathrm{~T} \quad 1 \mathrm{H} \quad-2.760317369541 \mathrm{E}-01-2.804782658929 \mathrm{E}+00-3.227101175863 \mathrm{E}-01$ $118 \mathrm{~T} \quad 1 \mathrm{H} \quad-2.204734691397 \mathrm{E}-01 \quad 1.290413370585 \mathrm{E}+00 \quad 2.118262361474 \mathrm{E}+00$ $\begin{array}{llllll}119 \mathrm{~T} & 1 \mathrm{H} & -2.199947210395 \mathrm{E}-01 & 1.244148547264 \mathrm{E}+00 & 4.592924784482 \mathrm{E}+00\end{array}$ $120 \mathrm{~T} \quad 1 \mathrm{H} \quad-1.638323850925 \mathrm{E}-01-1.539466086865 \mathrm{E}-01 \quad 5.809548265307 \mathrm{E}+00$ $121 \mathrm{~T} \quad 1 \mathrm{H} \quad-1.082978225403 \mathrm{E}-01-1.507901980773 \mathrm{E}+00 \quad 4.519850965840 \mathrm{E}+00$ $122 \mathrm{~T} \quad 1 \mathrm{H} \quad-1.090682604553 \mathrm{E}-01-1.467318188911 \mathrm{E}+00 \quad 2.045252380452 \mathrm{E}+00$ $\begin{array}{llllll}123 \mathrm{~T} & 6 \mathrm{C} 1 & 3.319455205297 \mathrm{E}-02 & 2.072518804814 \mathrm{E}+00 & 1.820681118625 \mathrm{E}+00\end{array}$ $\begin{array}{llllll}124 \mathrm{~T} & 6 \mathrm{C} 1 & 3.324535222362 \mathrm{E}-02 & 3.272525923866 \mathrm{E}+00 & 2.525309330780 \mathrm{E}+00\end{array}$ $\begin{array}{llllll}125 \mathrm{~T} & 6 \mathrm{C} 1 & 1.826042937986 \mathrm{E}-03 & 4.272152614298 \mathrm{E}+00 & 2.223288945727 \mathrm{E}+00\end{array}$ $\begin{array}{llllll}126 \mathrm{~T} & 6 \mathrm{C} 1 & -2.974599362039 \mathrm{E}-02 & 4.056223473047 \mathrm{E}+00 & 1.205701885553 \mathrm{E}+00\end{array}$ $\begin{array}{lllll}127 \mathrm{~T} & 6 \mathrm{C} 1 & -2.996224055983 \mathrm{E}-02 & 2.858322364336 \mathrm{E}+00 & 4.976504533394 \mathrm{E}-01\end{array}$ $\begin{array}{llllll}128 \mathrm{~T} & 1 \mathrm{H} & 5.730218319954 \mathrm{E}-02 & 1.293223275566 \mathrm{E}+00 & 2.068125016808 \mathrm{E}+00\end{array}$ $\begin{array}{llllll}129 & \mathrm{~T} & 1 \mathrm{H} & 5.768774086406 \mathrm{E}-02 & 3.427104809436 \mathrm{E}+00 & 3.321711791861 \mathrm{E}+00\end{array}$ $\begin{array}{llllll}130 \mathrm{~T} & 1 \mathrm{H} & 1.936885990871 \mathrm{E}-03 & 5.209352797540 \mathrm{E}+00 & 2.775146895180 \mathrm{E}+00\end{array}$ $\begin{array}{lllll}131 \mathrm{~T} & 1 \mathrm{H} & -5.409608554670 \mathrm{E}-02 & 4.831115811198 \mathrm{E}+00 & 9.573293802929 \mathrm{E}-01\end{array}$ $132 \mathrm{~T} \quad 1 \mathrm{H} \quad-5.420591512015 \mathrm{E}-02 \quad 2.699812399824 \mathrm{E}+00 \quad-3.008957401356 \mathrm{E}-01$

\section{$\mathrm{T}=$ ATOM BELONGING TO THE ASYMMETRIC UNIT}


1.2. Helical polymers. Three magnetic centres per cell.

Polymer 1b. Magnetic atoms: 7, 8, 21.

FINAL OPTIMIZED GEOMETRY - DIMENSIONALITY OF THE SYSTEM 1 (NON PERIODIC DIRECTION: LATTICE PARAMETER FORMALLY SET TO 500)

$* * * * * * * * * * * * * * * * * * * * * * * * * * * * * * * * * * * * * * * * * * * * * * * * * * * * * * * * * * * * * * * * * * * * * * * * * * * * * * * * * * * * * * * * * * * * *$

LATTICE PARAMETERS (ANGSTROMS AND DEGREES) - BOHR $=0.5291772083$ ANGSTROM PRIMITIVE CELL

A $\quad$ B $\quad \mathrm{C} \quad$ ALPHA BETA GAMMA

$\begin{array}{llllll}6.16269310 & 500.00000000 & 500.00000000 & 90.000000 & 90.000000 & 90.000000\end{array}$

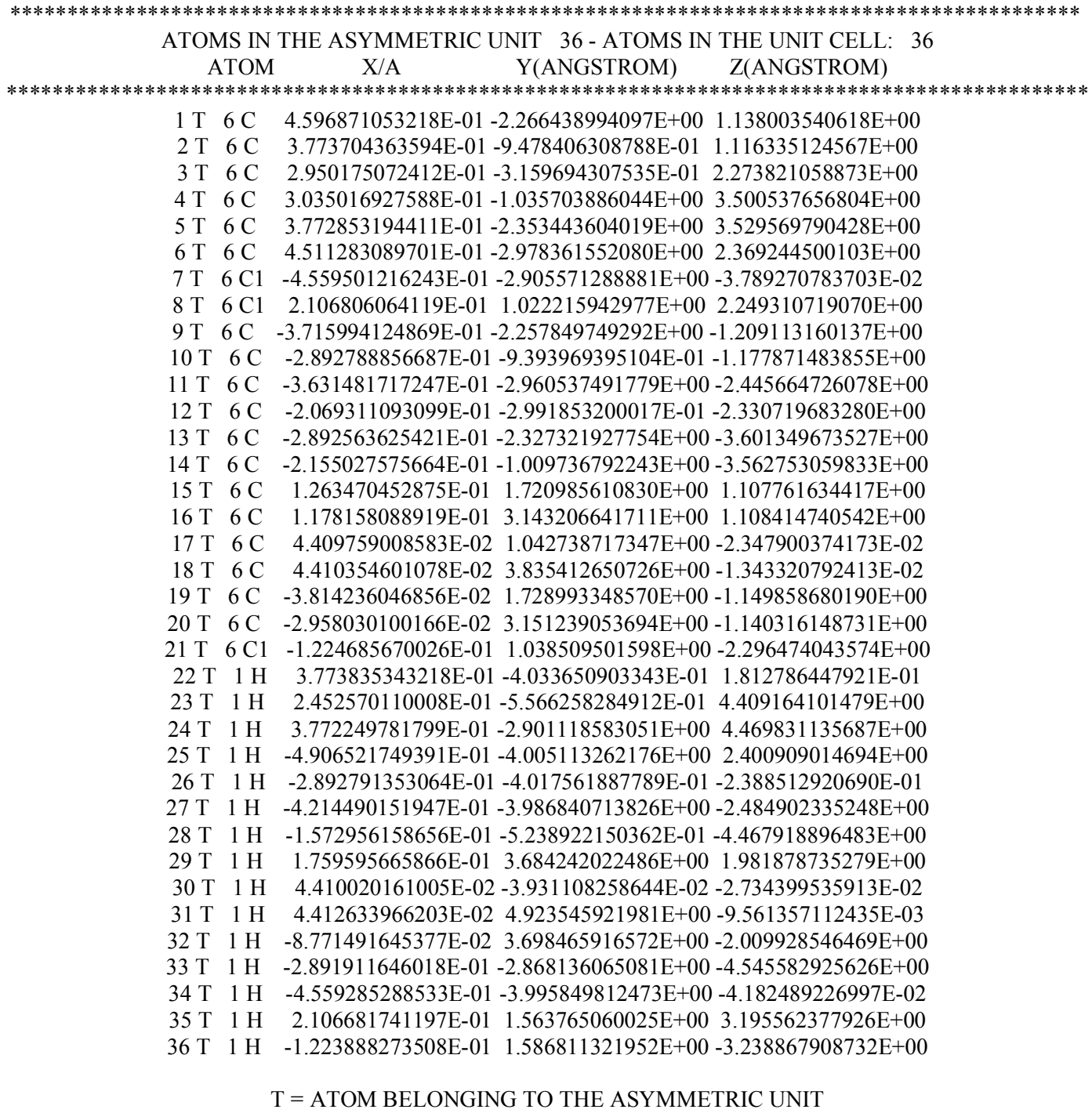


Polymer 2b. Magnetic atoms: 7, 14, 21.

FINAL OPTIMIZED GEOMETRY - DIMENSIONALITY OF THE SYSTEM 1 (NON PERIODIC DIRECTION: LATTICE PARAMETER FORMALLY SET TO 500)

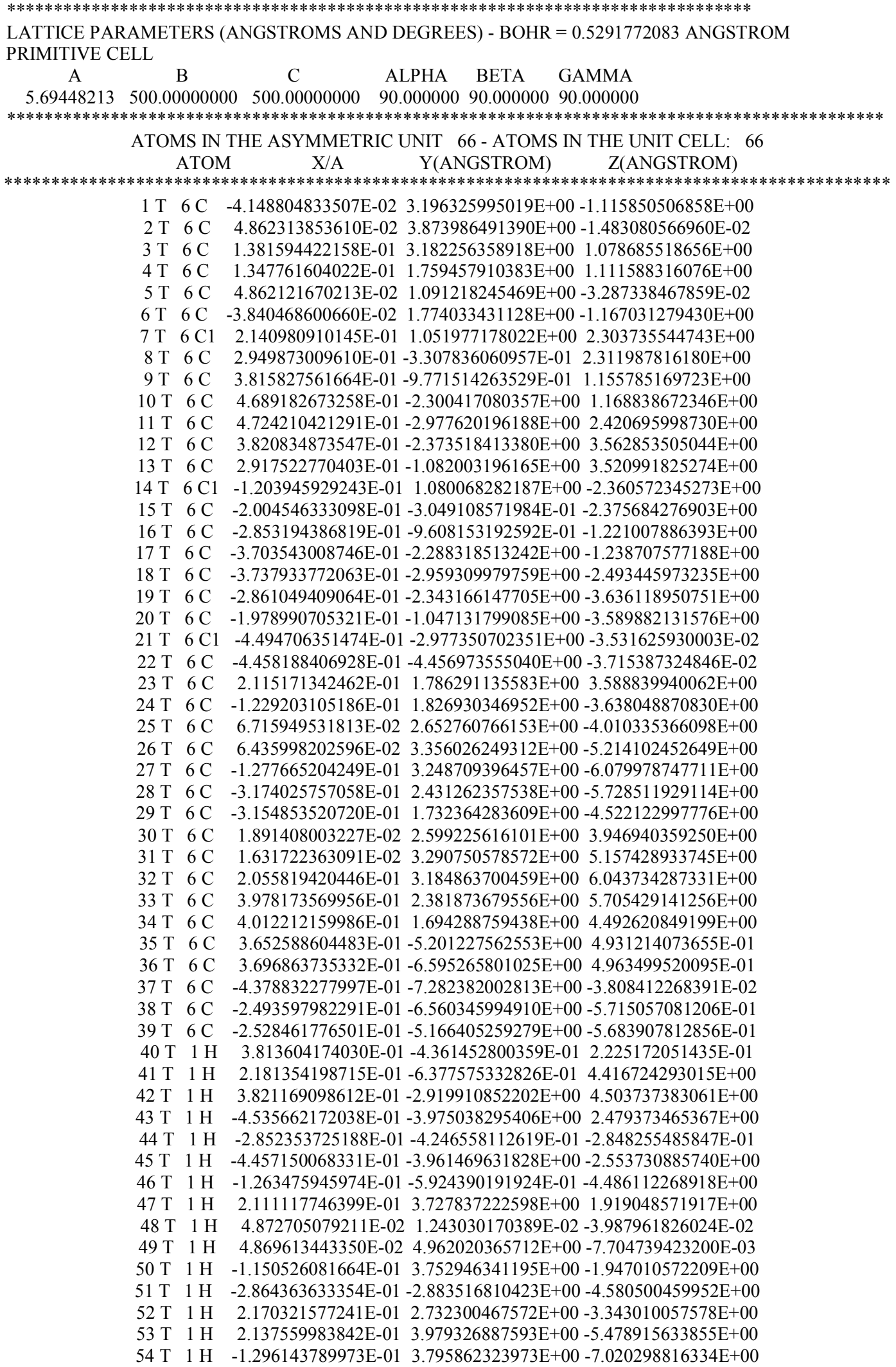


$55 \mathrm{~T} \quad 1 \mathrm{H} \quad-4.683543913251 \mathrm{E}-01 \quad 2.343446084517 \mathrm{E}+00-6.388980560885 \mathrm{E}+00$

$\begin{array}{lllll}56 \mathrm{~T} & 1 \mathrm{H} & -4.632574562635 \mathrm{E}-01 & 1.102962210232 \mathrm{E}+00 & -4.248110744801 \mathrm{E}+00\end{array}$

$\begin{array}{llllll}57 \mathrm{~T} & 1 \mathrm{H} & -1.287514771446 \mathrm{E}-01 & 2.676824092223 \mathrm{E}+00 & 3.263359835619 \mathrm{E}+00\end{array}$

$\begin{array}{llllll}58 \mathrm{~T} & 1 \mathrm{H} & -1.349768548872 \mathrm{E}-01 & 3.903735436809 \mathrm{E}+00 & 5.411039623586 \mathrm{E}+00\end{array}$

$\begin{array}{llllll}59 \mathrm{~T} & 1 \mathrm{H} & 2.031551849346 \mathrm{E}-01 & 3.721676780910 \mathrm{E}+00 & 6.989910238306 \mathrm{E}+00\end{array}$

$\begin{array}{llllll}60 \mathrm{~T} & 1 \mathrm{H} & -4.532678218794 \mathrm{E}-01 & 2.296499713367 \mathrm{E}+00 & 6.381261889862 \mathrm{E}+00\end{array}$

$\begin{array}{llllll}61 \mathrm{~T} & 1 \mathrm{H} & -4.490448805941 \mathrm{E}-01 & 1.075656614894 \mathrm{E}+00 & 4.229418639791 \mathrm{E}+00\end{array}$

$62 \mathrm{~T} \quad 1 \mathrm{H} \quad 2.151848834817 \mathrm{E}-01-4.669751780430 \mathrm{E}+00 \quad 9.015341347227 \mathrm{E}-01$

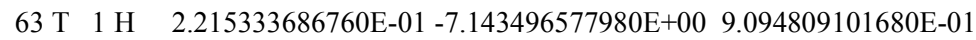

$64 \mathrm{~T} \quad 1 \mathrm{H} \quad-4.348885796676 \mathrm{E}-01-8.370207577534 \mathrm{E}+00-3.911015232024 \mathrm{E}-02$

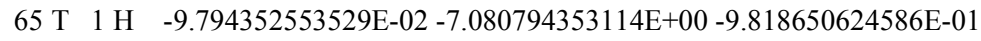

$66 \mathrm{~T} \quad 1 \mathrm{H} \quad-1.058018024569 \mathrm{E}-01-4.607723670092 \mathrm{E}+00-9.763690794541 \mathrm{E}-01$

$\mathrm{T}=$ ATOM BELONGING TO THE ASYMMETRIC UNIT 


\section{Energy expressions, computed absolute energies and definition of magnetic solutions required for the extraction of magnetic exchange interactions.}

All periodic calculation performed in this work have been carried out using CRYSTAL09 program. ${ }^{1,2}$ The CRYSTAL program computes the electronic structure of periodic systems within Hartree Fock, density functional or various hybrid approximations, and expresses the Bloch functions of the periodic systems as linear combinations of atom centred Gaussian functions. These serve to define the crystalline orbitals, from which all one-electron properties are calculated, such as population analysis, band structure or density of states.

All performed calculations are spin-unrestricted, where the number of unpaired electrons in the cell is fixed, through the keyword SPINLOCK.

This section exemplifies the extraction of the most relevant magnetic exchange interactions in the two studied cases: a linear chain and a helical structure of arranged spins.

The model spin Hamiltonian that describes the pure spin states of the system is the well-known Heisenberg-Dirac-VanVleck Hamiltonian. ${ }^{3,5}$ This Hamiltonian describes the isotropic interaction between localized magnetic moments $\boldsymbol{S}_{i}$ and $\boldsymbol{S}_{j}$ as

$$
\begin{aligned}
\widehat{H}^{H D V V} & =-\sum_{\langle i, j\rangle} J_{i j} \widehat{\boldsymbol{S}}_{i} \cdot \widehat{\boldsymbol{S}}_{j} \\
& =-\sum_{\langle i, j\rangle} J\left(1 / 2\left[\hat{S}_{i+} \hat{S}_{j-}+\hat{S}_{i-} \hat{S}_{j+}\right]+\hat{S}_{i}^{Z} \cdot \hat{S}_{j}^{z}\right.
\end{aligned}
$$

where $J_{i j}$ is the exchange coupling constant between the $\widehat{\boldsymbol{S}}_{i}$ and $\widehat{\boldsymbol{S}}_{j}$ localized spin moments and the $\langle i, j\rangle$ symbol indicates that the sum refers to nearest neighbour interactions only. According to the adopted definition in eqn (1), a positive value of the exchange coupling constant $J_{i j}$ corresponds to ferromagnetic interactions, while negative values describe an antiferromagnetic interaction (parallel and antiparallel spins alignments respectively). The number, sign and magnitude of the most relevant $J_{i j}$ determine the low-energy spectrum of the problem and consequently the magnetic ordering of the system. It is worth noting that spin adapted wave functions are also 
eigenfunctions of the total squared spin operator $\hat{S}^{2}=\widehat{\boldsymbol{S}}_{x} \cdot \widehat{\boldsymbol{S}}_{x}+\widehat{\boldsymbol{S}}_{y} \cdot \widehat{\boldsymbol{S}}_{y}+\widehat{\boldsymbol{S}}_{z} \cdot \widehat{\boldsymbol{S}}_{z}$, given that $\left[\widehat{H}^{H D V V}, \hat{S}^{2}\right]=0$.

In a periodic system, calculating the spin adapted wavefunction is very complicated, and a simplification is required. This simplification is given by adopting the Ising $^{6}$ spin Hamiltonian, which results from neglecting the ladder operator terms in eqn (1) and retaining the $z$-component of $\boldsymbol{S}$ (i.e. the diagonal term of HDVV). Therefore, for a given system, the Ising Hamiltonian is expressed as

$$
\widehat{H}^{I s i n g}=-\sum_{<i, j>} J_{i j} \cdot \hat{S}_{i}^{z} \cdot \hat{S}_{j}^{z}
$$

where $J_{i j}$ is the exchange coupling constant between centres $i$ and $j$ and the $\langle i, j\rangle$ symbol indicates that the sum refers to nearest neighbour interactions only. $\hat{S}_{i}^{z}$ is the zcomponent of the spin operator. If this operator acts on a $\alpha$ spin (spin-up), the expected value is $+1 / 2$. If the operator acts on a $\beta$ spin (spin-down), the expected value is $-1 / 2$.

Now, one has to define a proper mapping procedure to ensure that the energy differences calculated with broken symmetry solutions (eigenfunctions of the Ising Hamiltonian) represent energy differences between spin adapted functions (eigenfunctions of the HDVV Hamiltonian). At this point it is worth realizing that, when written in the same basis set (neutral determinants), the diagonal elements of the matrix representation of both Hamiltonians coincide, and therefore one can use this fact to directly map the energy of the broken symmetry solutions to the energy expectation values in the HDVV Hamiltonian. Therefore, what is left is to access to as many magnetic solutions as required to extract all relevant magnetic coupling constants, which is done by defining the appropriate magnetic cell, so here the discussion is restricted to show how to apply the Ising Hamiltonian to periodic systems to extract the $J_{i j}$ values.

The number of exchange coupling constant relevant for defining the low-lying magnetic solutions depends on the system under study, being different for the linear and helical case. One has to make sure to count with the necessary solutions that allow solving the system of equations for all important exchange coupling constants; that is, if there are $N$ relevant exchange coupling constant, it is required to have $(N+1)$ different 
solutions that yield a set of $N$ linearly independent equations, at least. The parameter that allows defining the convenient amount of solutions is the magnetic cell. The unit cell is the most basic repeating structure needed to replicate the nuclear coordinates in an ordered crystal, but it might not be sufficient to replicate the magnetic order of interest. Then, by discarding some spatial symmetry operations, it is possible to define a larger cell containing the sufficient number of magnetic centres to describe the magnetic solutions of interest. Once the magnetic cell is defined, the different magnetic solutions are defined by considering successive spin-reversals in each of the magnetic centres. Thus, the ferromagnetic solution (FM) displays all of the magnetic centres with the highest $S$ value and the different antiferromagnetic solutions $\left(\mathrm{AFM}_{i} i=1, N-1\right)$ represent combinations of all possible $S$ values. Additionally, being able to define different magnetic cells allows checking whether the extracted exchange coupling values are consistent.

Prior to describing each of the situations in detail, let us highlight the common aspects for obtaining the energy expressions when applying the Ising Hamiltonian (eqn(2)). Since the magnetic interaction involves pairs of neighbours, those interacting inside the magnetic cell contribute with one exchange coupling constant, while those interactions crossing the magnetic cell contribute with half the exchange coupling constant. If the interaction is between centres of the same spin, the sign of the exchange coupling constant is negative, while if different spin centres are involved, the sign becomes positive. In order to justify this consider two electrons (A and B) with spin-up interacting. According to eqn (2), their interaction is described as $\widehat{H}^{I s i n g}=-J \hat{S}_{A}^{Z} \cdot \hat{S}_{B}^{Z}=$ $-J \cdot 1 / 2 \cdot 1 / 2=-J / 4$. Similarly, if the $A$ and $B$ electrons have spin-down, their interaction is described as $\widehat{H}^{I s i n g}=-J \hat{S}_{A}^{Z} \cdot \hat{S}_{B}^{Z}=-J \cdot(-1 / 2) \cdot(-1 / 2)=-J / 4$. Finally, if electrons A and B have different spin, the sign of the interaction is reversed $\widehat{H}^{\text {Ising }}=-J \hat{S}_{A}^{z} \cdot \hat{S}_{B}^{Z}=-J \cdot(-1 / 2) \cdot 1 / 2=+J / 4$.

\subsection{Linear conformation.}

The magnetic cell used for the extraction of the magnetic interactions is the same cell used for the optimization of the polymer, and therefore contains six magnetic centres. Consider Figure S. I. 1 as a simple linear arrangement of nearly equally distanced $S=1 / 2$ magnetic centres. By choice, the magnetic cell presents six magnetic centres, as indicated by the brackets. Assuming that the most relevant magnetic 
interactions are those involving nearest $\left(J_{1}\right)$ and second-nearest $\left(J_{2}\right)$ neighbours only, three magnetic solutions are required in order to have two energetic differences that provide enough equations. Those solutions are named $\mathrm{FM}, \mathrm{AFM}_{1}$ and $\mathrm{AFM}_{2} ; \mathrm{FM}$ corresponds to the high-spin case (all magnetic centres are forced to have the same spin) and $\mathrm{AFM}_{1}$ and $\mathrm{AFM}_{2}$ present one and two spin-down respectively. As an example, the calculation of the energy expression for the FM case is inspected in more detail. Following these arguments, the rest of the expressions are easy to obtain. Thus, there are 5 nearest neighbours interactions inside the magnetic cell and two (one from the left and one from the right extremes, contributing half each) outside the cell. Since all the spins are up in the FM solution, it results in $-6 J_{1}\left(\frac{1}{2}\right)^{2}$. For the second neighbour's interactions, there are 4 inside the magnetic cell and 4 more (which correspond to 2) outside the magnetic cell. Again, given that all centres have the same spin, it results in $-6 J_{2}\left(\frac{1}{2}\right)^{2}$. The sum of these two terms corresponds to $-6 / 4\left(J_{1}+J_{2}\right)$. Following this reasoning, the expression for the $\mathrm{AFM}_{1}$ and $\mathrm{AFM}_{2}$ in Figure S. I. 1 are easy to check. The only difference is that those interactions involving electrons of different spin imply a reversal of the magnetic coupling constant sign. One is left with two linearly independent energy differences expressions. Then, by computing these solutions within the CRYSTAL program, the actual energetic values can be obtained and the set of equations solved.

The computed absolute energies for the different magnetic solutions are given in Table S. I. 1. The associated energy expressions according to the Ising Hamiltonian and the computed energetic differences for the solutions FM-AFM2 are indicated in Table S. I. 2. Figure S. I. 1 specifies how the different FM-AFM2 magnetic solutions are defined. Thus, in order to extract the relevant magnetic coupling constants one has only to solve the set of equations of $\Delta \mathrm{E}_{\mathrm{FM}-\mathrm{AFM} 1}$ and $\Delta \mathrm{E}_{\mathrm{FM}-\mathrm{AFM} 2}$ indicated in Table $\mathrm{S}$. I. 2.

Table S. I. 1. Absolute computed energies for the different magnetic solutions required for the extraction of the magnetic exchange constants.

\begin{tabular}{ccc}
\cline { 2 - 3 } & \multicolumn{2}{c}{ Energy (hartree) } \\
\hline Solution & 1a & 2a \\
\hline FM & -1616.4013668690 & -3001.1249851480 \\
AFM1 & -1616.3926198107 & -3001.1196340643 \\
AFM2 & -1616.3928287815 & -3001.1198010527
\end{tabular}


Table S. I. 2. Energy expressions associated to each of the magnetic solutions in the linear conformation. Computed absolute energies and associated energy differences referred to the ferromagnetic phase for all magnetic cells used in the helical conformation.

\begin{tabular}{ccc|cc}
\hline Solution & energy & $\Delta \mathrm{E}_{\mathrm{FM}-\mathrm{AFM}}$ & \multicolumn{2}{c}{ Calculated $\Delta \mathrm{E}_{\mathrm{FM}-\mathrm{AFM}}(\mathrm{cm}-1)$} \\
\hline FM & $-6 / 4\left(J_{1}+J_{2}\right)$ & & $\mathbf{1 a}$ & $\mathbf{2 a}$ \\
AFM1 & $-1 / 2\left(J_{1}+J_{2}\right)$ & $-J_{1}-J_{2}$ & -1919.75734 & -1174.427088 \\
AFM2 & $1 / 2\left(-J_{1}+J_{2}\right)$ & $-J_{1}-2 J_{2}$ & -1873.893552 & -1137.777372
\end{tabular}

Figure S. I. 1. Schematic representation of the magnetic solutions (indicated in brackets) used to extract all relevant magnetic interactions.
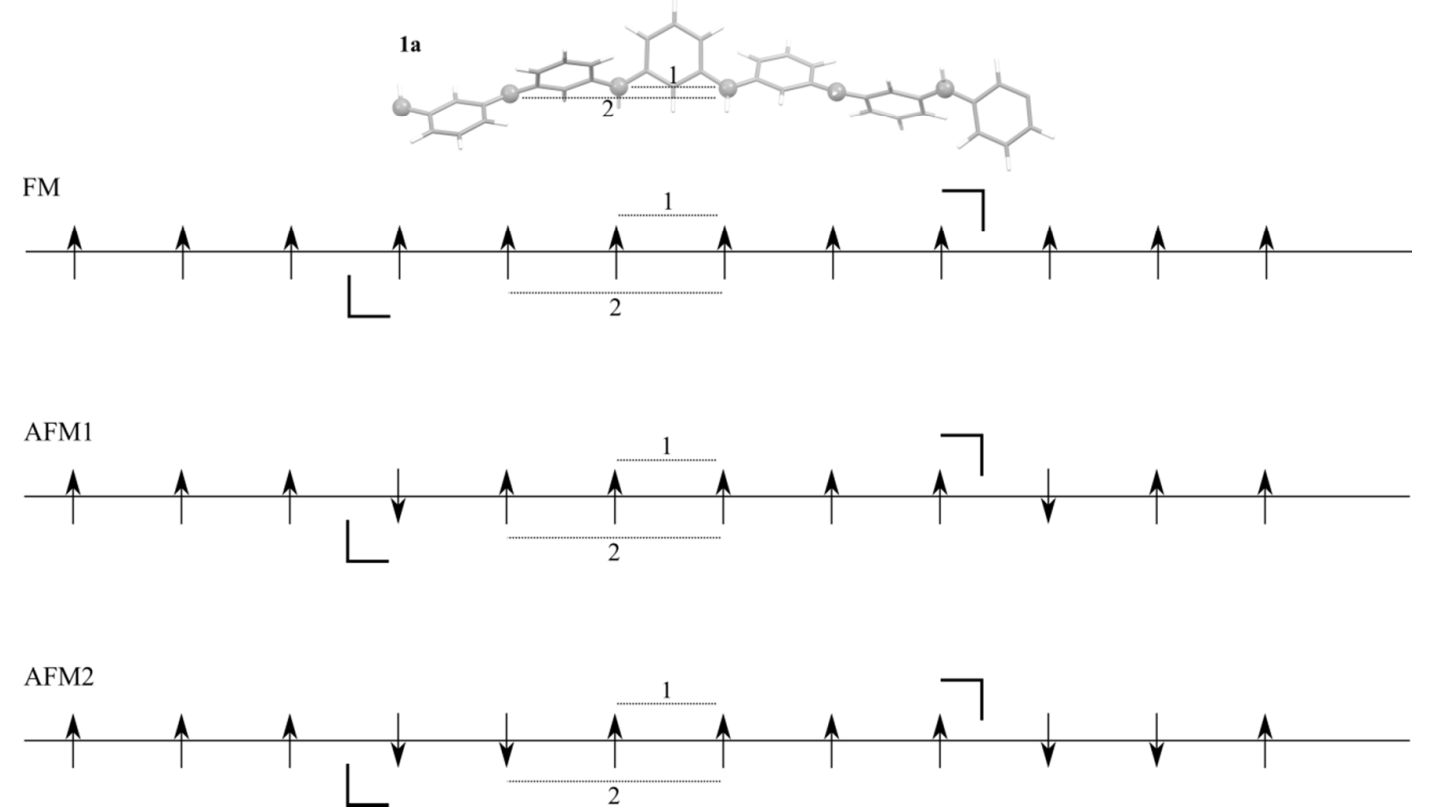

\subsection{Helical conformation.}

The magnetic cell used for the extraction of the magnetic interactions is double the cell used for the optimization of the polymer, and therefore contains six magnetic centres, as indicated by the brackets in Figure S. I. 2. If we kept a magnetic cell of three magnetic centres, we would only have three magnetic solutions (one with all spins up, one with one spin down and one with two spins down) resulting in only two energy differences. This is obviously not enough to extract the four most relevant magnetic coupling constants occurring in the system. Following the same reasoning as for the linear case, in the helical problem there are 5 nearest neighbours interactions inside the 
magnetic cell and two (one from the left and one from the right extremes, contributing half each) outside the cell. For the second-nearest neighbours, there are 3 interactions inside the cell and 6 outside the cell. For the third-nearest neighbours, there are 4 interactions inside the cell and 4 outside the cell. For the fourth-nearest neighbours, there are 2 interactions inside the cell and 4 outside the cell. Now, depending on which magnetic solution is considered, the signs of the interactions change, resulting in the final expressions, indicated in Table S. I. 4.

The computed absolute energies for the different magnetic solutions are given in Table S. I. 3. The associated energy expressions according to the Ising Hamiltonian and the computed energetic differences for the solutions FM-AFM4 are indicated in Table S. I. 4. Figure S. I. 2 specifies how the different FM-AFM4 magnetic solutions are defined.

Table S. I. 3 Absolute computed energies for the different magnetic solutions required for the extraction of the magnetic exchange constants.

\begin{tabular}{ccc}
\cline { 2 - 3 } & \multicolumn{2}{c}{ Energy (hartree) } \\
\hline Solutions & 2a & 2b \\
\hline FM & -1616.427910044 & -3001.151038859 \\
AFM1 & -1616.417569494 & -3001.143326321 \\
AFM2 & -1616.407237511 & -3001.135616547 \\
AFM3 & -1616.407225306 & -3001.135559183 \\
AFM4 & -1616.417829211 & -3001.143528848
\end{tabular}

Table S. I. 4. Energy expressions and the resulting energy difference referred to the ferromagnetic phase for all magnetic cells used in the helical conformation.

\begin{tabular}{ccc|cc}
\hline cell & energy & $\Delta \mathrm{E}_{\mathrm{FM}-\mathrm{AFM}}$ & \multicolumn{2}{c}{ Calculated $\Delta \mathrm{E}_{\mathrm{FM}-\mathrm{AFM}(\mathrm{cm}-1)}$} \\
\hline FM & $1 / 2\left(-3 J_{1}-3 J_{2}-3 J_{3}-2 J_{4}\right)$ & & $\mathbf{1 b}$ & $\mathbf{2 b}$ \\
AFM1 & $1 / 2\left(-J_{1}-J_{2}-J_{3}\right)$ & $-J_{1}-J_{2}-J_{3}-J_{4}$ & -2269.5 & -1692.7 \\
AFM2 & $1 / 2\left(J_{1}-3 J_{2}+J_{3}+J_{4}\right)$ & $-2 J_{1}-2 J_{3}-2 J_{4}$ & -4537.1 & -3384.8 \\
AFM3 & $1 / 2\left(J_{1}+J_{2}+J_{3}+J_{4}\right)$ & $-2 J_{1}-2 J_{2}-2 J_{3}-\frac{3}{2} J_{4}$ & -4539.8 & -3397.4 \\
AFM4 & $1 / 2\left(-J_{1}+J_{2}+J_{3}+J_{4}\right)$ & $-J_{1}-2 J_{2}-2 J_{3}-\frac{3}{2} J_{4}$ & -2212.5 & -1648.3
\end{tabular}


Figure S. I. 2. Schematic representation of the magnetic cells (indicated in brackets) used to extract all relevant magnetic interactions. Pale grey indicated depth.
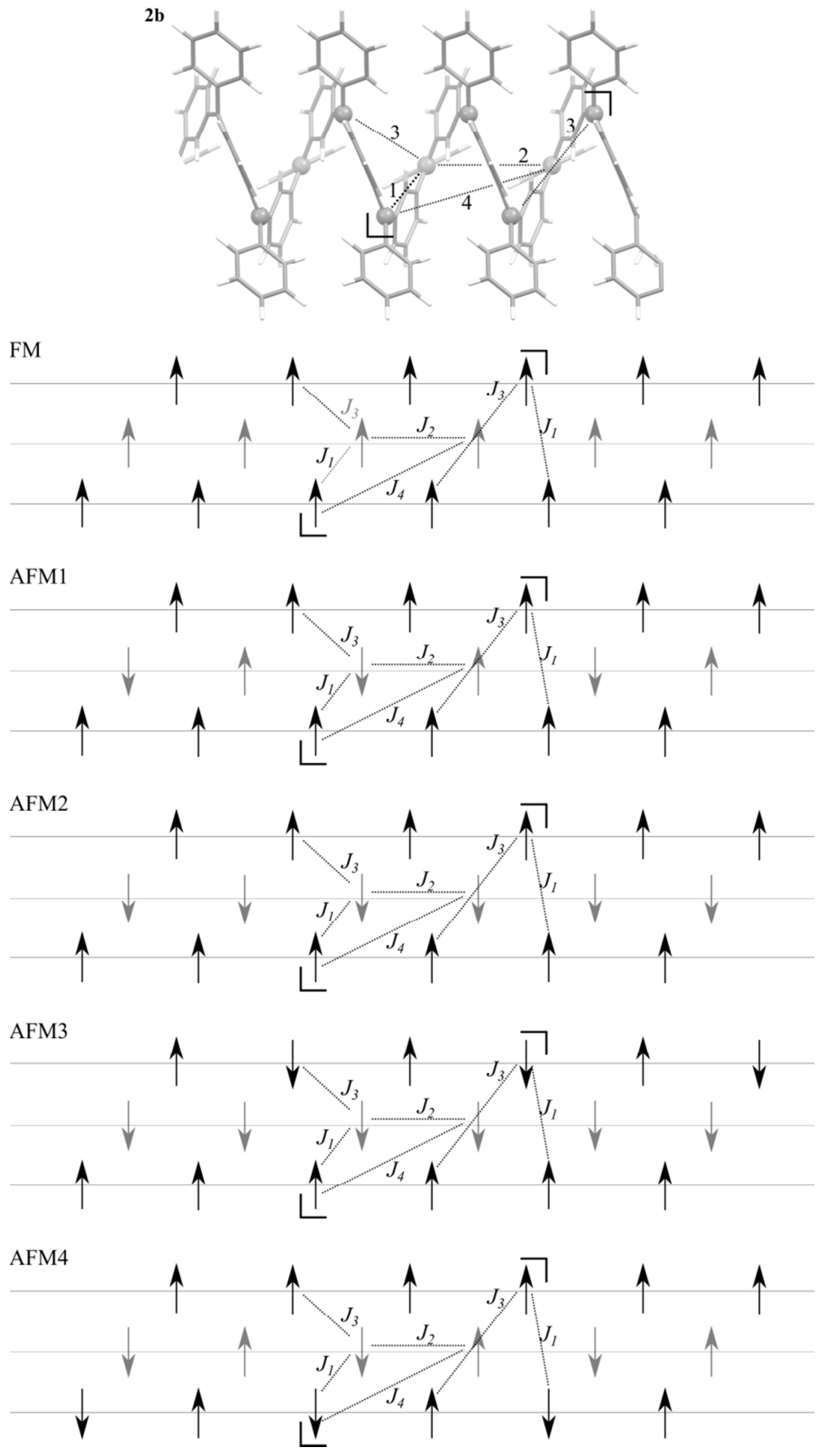


\section{Density of States and Band Structure plots for FM and AFM solutions of polymer $2 b$.}

Figure S. I. 3 represents the density of states for both ferro and antiferromagnetic solutions. Note that the AFM solution is defined as the solution where each single spin is surrounded by two spins of opposite sign. This solution was not used to compute the exchange coupling constants in the previous section, but is normally the reference for reporting band gap values, since it represents the most unfavourable case for ferromagnetic ordering. In line with what was discussed in the main text, the value of the band gap is 2 and $1.7 \mathrm{eV}$ for FM and AFM solutions respectively. This is an indication of the stability of the radical centres and of the robustness of the magnetic properties. 
Figure S. I. 3. Density of states of ferromagnetic (FM) and antiferromagnetic (AFM) solutions of polymer $\mathbf{2} \mathbf{b}$. The definition of the magnetic cell used is also indicated.
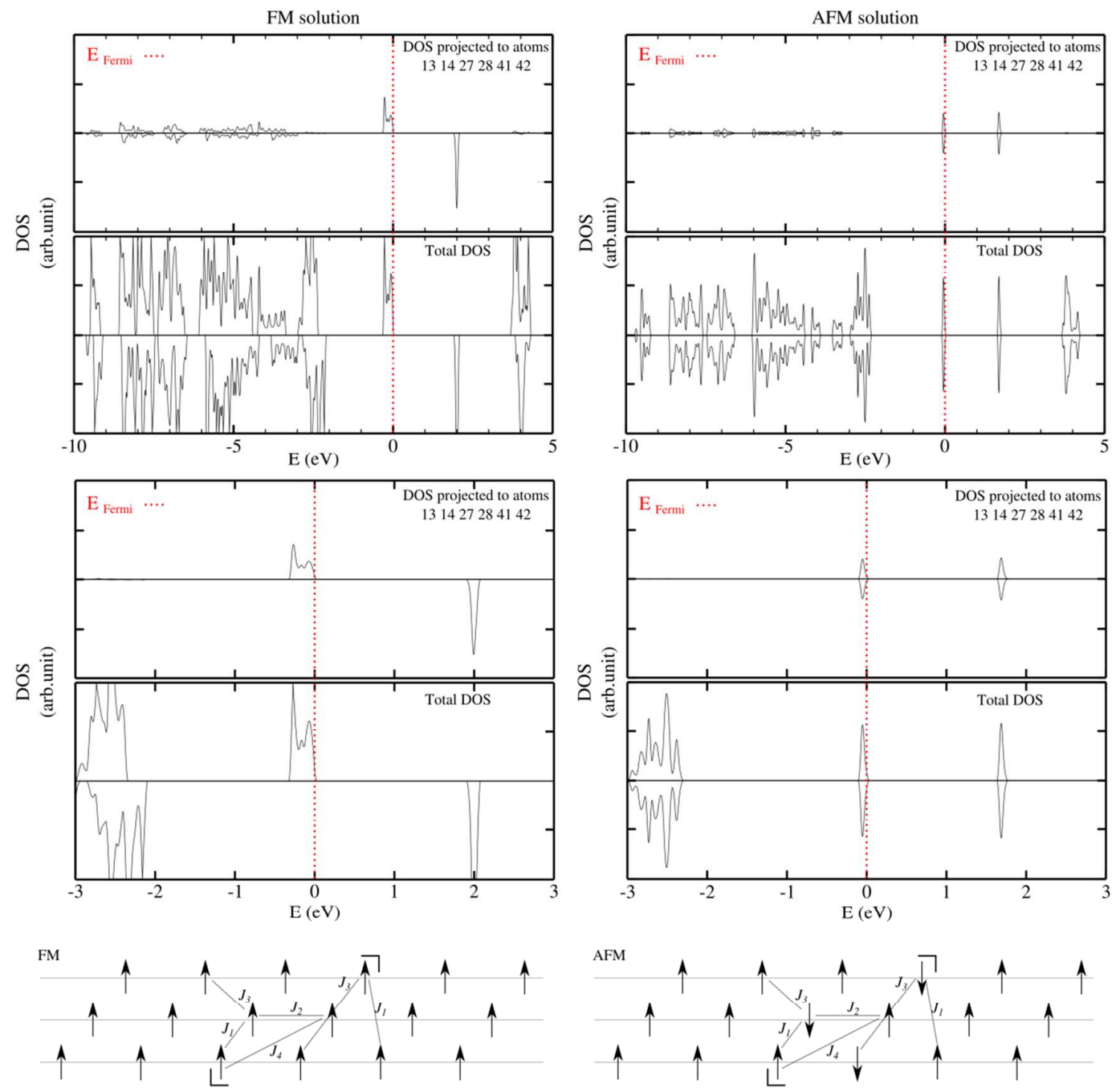
Figure S. I. 4 introduces the band diagram for both ferro and antiferromagnetic solutions as defined for the density of states representations. As it can be seen, the bands are quite flat and show little dispersion.

Figure S. I. 4. Band diagram of ferro and antiferro solutions of polymer $\mathbf{2 b}$.

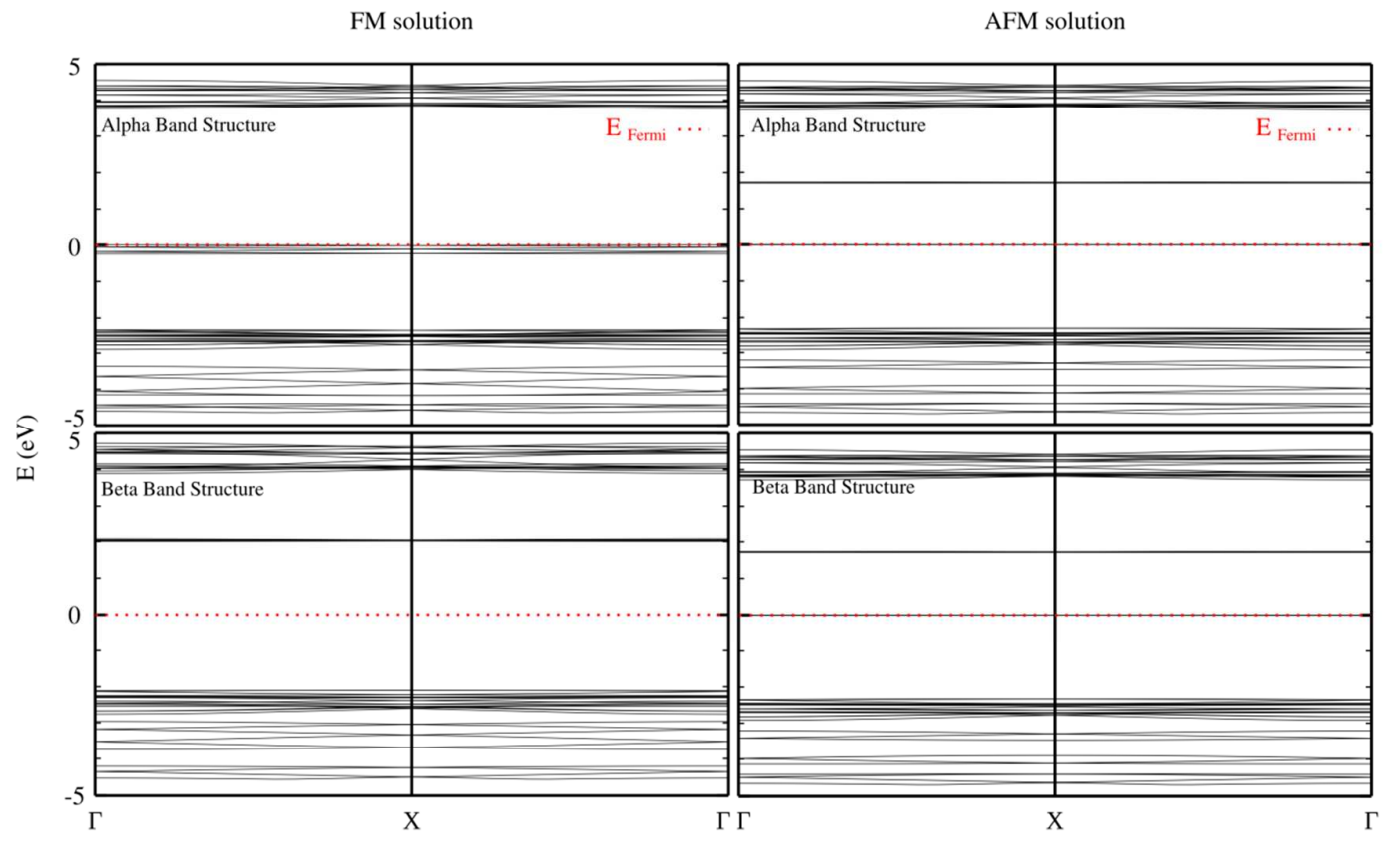


4. Optimized geometries (high-spin solution) of the different decaradicals derived from polymers $1 \mathrm{~b}$ and $\mathbf{2 b}$ and calculated energetic differences for the decaradical derived from polymer $2 \mathrm{~b}$.

4.1.Optimized geometry of discrete helical decaradical derived from $\mathbf{1 b}$.

$\begin{array}{lrrr}\mathrm{C} & 1.48395900 & -3.37023600 & 3.49746500 \\ \mathrm{C} & 0.68607200 & -2.80817300 & 4.48794500 \\ \mathrm{C} & 0.56237600 & -1.42665600 & 4.59661400 \\ \mathrm{C} & 1.24599600 & -0.56507700 & 3.69501700 \\ \mathrm{C} & 2.13257800 & -1.15368000 & 2.76557000 \\ \mathrm{C} & 2.24173100 & -2.55651300 & 2.60521500 \\ \mathrm{C} & 0.97900700 & 0.83984300 & 3.78009000 \\ \mathrm{C} & 1.12135800 & 1.87207300 & 2.80324000 \\ \mathrm{C} & 1.46345100 & 1.65815800 & 1.44720900 \\ \mathrm{C} & 1.53062500 & 2.70892300 & 0.50502600 \\ \mathrm{C} & 1.28341200 & 4.02978700 & 0.97653000 \\ \mathrm{C} & 0.92604400 & 4.26267100 & 2.30094200 \\ \mathrm{C} & 0.82776600 & 3.20721200 & 3.20373700 \\ \mathrm{C} & 1.86741500 & 2.55190100 & -0.87353100 \\ \mathrm{C} & 2.04006500 & 1.37634500 & -1.66869300 \\ \mathrm{C} & 1.54499400 & 0.09918800 & -1.32592200 \\ \mathrm{C} & 1.83673200 & -1.05959400 & -2.08138600 \\ \mathrm{C} & 2.60658900 & -0.88141900 & -3.26669700 \\ \mathrm{C} & 3.01962900 & 0.38228200 & -3.67528400 \\ \mathrm{C} & 2.74303500 & 1.50251700 & -2.89732200 \\ \mathrm{C} & 1.44076500 & -2.39590000 & -1.76553600 \\ \mathrm{C} & 0.61015600 & -2.96068800 & -0.75087300 \\ \mathrm{C} & -0.03908600 & -2.25240200 & 0.28578500 \\ \mathrm{C} & -0.94706200 & -2.86812400 & 1.17448200 \\ \mathrm{C} & -1.11675800 & -4.27676300 & 1.07940000 \\ \mathrm{C} & -0.44578900 & -5.00680400 & 0.10270800 \\ \mathrm{C} & 0.38851800 & -4.36771500 & -0.80910600 \\ \mathrm{C} & -1.67636800 & -2.16742700 & 2.18143500 \\ \mathrm{C} & -1.91692300 & -0.76888100 & 2.35227500 \\ \mathrm{C} & -1.71716400 & 0.20958800 & 1.35088700 \\ \mathrm{C} & -1.98313400 & 1.58038700 & 1.56537800 \\ \mathrm{C} & -2.44701700 & 1.95871000 & 2.85839200 \\ \mathrm{C} & -2.68860500 & 1.00927900 & 3.84482000 \\ \mathrm{C} & -2.44584500 & -0.33898900 & 3.59986000 \\ \mathrm{C} & -1.82450300 & 2.63450800 & 0.61337700 \\ \mathrm{C} & -1.51002300 & 2.66791900 & -0.77923300 \\ \mathrm{C} & -1.38777400 & 1.55040400 & -1.63261400 \\ \mathrm{C} & -1.03876900 & 1.67149800 & -2.99897200 \\ \mathrm{C} & -0.78159300 & 2.97708700 & -3.50359300 \\ \mathrm{C} & -0.92907800 & 4.09675200 & -2.68876400 \\ \mathrm{C} & -1.29970800 & 3.95460900 & -1.35613700 \\ \mathrm{C} & -0.84839700 & 0.56493600 & -3.88163400 \\ \mathrm{C} & -1.15298700 & -0.82154100 & -3.70276200\end{array}$




\begin{tabular}{|c|c|c|c|}
\hline $\mathrm{C}$ & -2.09448600 & -1.31309600 & -2.76929100 \\
\hline $\mathrm{C}$ & -2.27608500 & -2.69757900 & -2.53575700 \\
\hline $\mathrm{C}$ & -1.53692800 & -3.59513900 & -3.36220800 \\
\hline $\mathrm{C}$ & -0.66877500 & -3.12980600 & -4.34305900 \\
\hline $\mathrm{C}$ & -0.46873900 & -1.76402400 & -4.51857300 \\
\hline $\mathrm{C}$ & -3.10227200 & -3.28712800 & -1.53006400 \\
\hline $\mathrm{C}$ & -3.90144800 & -2.75756400 & -0.46777300 \\
\hline $\mathrm{C}$ & -4.12532600 & -1.39045300 & -0.1865790 \\
\hline $\mathrm{C}$ & -4.95519300 & -0.95991600 & $0.8763960 \mathrm{C}$ \\
\hline $\mathrm{C}$ & -5.49750400 & -1.95299300 & 1.73933700 \\
\hline $\mathrm{C}$ & -5.27457800 & -3.30472400 & 1.49503900 \\
\hline $\mathrm{C}$ & -4.51249900 & -3.70843600 & 0.40352900 \\
\hline $\mathrm{C}$ & -5.23794800 & 0.40929600 & 1.16262800 \\
\hline $\mathrm{C}$ & -5.07623800 & 1.57554000 & 0.34574500 \\
\hline $\mathrm{C}$ & -4.88489000 & 1.55789900 & -1.05978100 \\
\hline $\mathrm{C}$ & -4.70085100 & 2.72582700 & -1.79473400 \\
\hline $\mathrm{C}$ & -4.73074700 & 3.96114500 & -1.12918600 \\
\hline $\mathrm{C}$ & -4.96249700 & 4.01395000 & 0.24891500 \\
\hline $\mathrm{C}$ & -5.14008400 & 2.84447500 & 0.97591000 \\
\hline $\mathrm{C}$ & -4.45005200 & 2.66877400 & -3.28149900 \\
\hline $\mathrm{C}$ & 3.01659900 & -3.23615700 & 1.61461900 \\
\hline $\mathrm{C}$ & 3.85824300 & -2.79516400 & 0.54574500 \\
\hline $\mathrm{C}$ & 4.14492400 & -1.45317200 & 0.20535500 \\
\hline $\mathrm{C}$ & 5.03814500 & -1.10721400 & -0.83585600 \\
\hline $\mathrm{C}$ & 5.58046300 & -2.16223300 & -1.62323600 \\
\hline $\mathrm{C}$ & 5.28594000 & -3.49017600 & -1.32991300 \\
\hline $\mathrm{C}$ & 4.45928000 & -3.81076100 & -0.25707400 \\
\hline $\mathrm{C}$ & 5.38275000 & 0.23586800 & -1.16799500 \\
\hline $\mathrm{C}$ & 5.19338400 & 1.44677000 & -0.42215600 \\
\hline $\mathrm{C}$ & 4.94045500 & 1.50567000 & 0.97235700 \\
\hline $\mathrm{C}$ & 4.72615100 & 2.71206200 & 1.63381100 \\
\hline $\mathrm{C}$ & 4.78078700 & 3.90851400 & 0.90224500 \\
\hline $\mathrm{C}$ & 5.07525500 & 3.88642600 & -0.46436400 \\
\hline $\mathrm{C}$ & 5.28940500 & 2.67904300 & -1.11646800 \\
\hline $\mathrm{C}$ & 4.43801900 & 2.74119500 & 3.11499800 \\
\hline $\mathrm{H}$ & -1.38716400 & -0.12143300 & 0.38346900 \\
\hline $\mathrm{H}$ & -3.59714700 & -0.63423800 & -0.73815800 \\
\hline $\mathrm{H}$ & 4.95175600 & 0.59312400 & 1.55758400 \\
\hline $\mathrm{H}$ & 1.67098900 & 0.65651300 & 1.11870000 \\
\hline $\mathrm{H}$ & -2.63603600 & -1.08179700 & 4.36986200 \\
\hline $\mathrm{H}$ & -4.35006300 & -4.76630500 & 0.21436400 \\
\hline $\mathrm{H}$ & 4.59597900 & 4.85311200 & 1.40783900 \\
\hline $\mathrm{H}$ & 0.53598200 & 3.39156100 & 4.23441900 \\
\hline $\mathrm{H}$ & -3.07043500 & 1.32285400 & 4.81363300 \\
\hline $\mathrm{H}$ & -5.70654000 & -4.05210500 & 2.15617600 \\
\hline $\mathrm{H}$ & 5.13294300 & 4.81888200 & -1.02111800 \\
\hline $\mathrm{H}$ & 0.71773900 & 5.27697600 & 2.63309700 \\
\hline $\mathrm{H}$ & 1.35127000 & 4.85425500 & 0.27227600 \\
\hline $\mathrm{H}$ & -2.63788300 & 3.01012300 & 3.05397300 \\
\hline $\mathrm{H}$ & -6.10459600 & -1.63802300 & 2.5842350 \\
\hline
\end{tabular}




$\begin{array}{lrrr} & & & \\ \mathrm{H} & 5.49989800 & 2.66084700 & -2.18259800 \\ \mathrm{H} & 0.87922700 & 0.03505700 & -0.48660900 \\ \mathrm{H} & -1.51745600 & 0.56315700 & -1.23016500 \\ \mathrm{H} & -4.92054500 & 0.61596700 & -1.59485500 \\ \mathrm{H} & 3.61802600 & -0.65025300 & 0.68698100 \\ \mathrm{H} & 3.09605200 & 2.48447100 & -3.19857700 \\ \mathrm{H} & -1.40565800 & 4.83024100 & -0.72190600 \\ \mathrm{H} & -5.29400300 & 2.88375200 & 2.05109000 \\ \mathrm{H} & 6.23968000 & -1.91311000 & -2.45093800 \\ \mathrm{H} & 2.85527600 & -1.75618800 & -3.86103300 \\ \mathrm{H} & -0.48154400 & 3.08749800 & -4.54247100 \\ \mathrm{H} & -4.57542200 & 4.87714500 & -1.69402800 \\ \mathrm{H} & 4.24712200 & -4.85142600 & -0.02522300 \\ \mathrm{H} & -1.79897700 & -4.76936100 & 1.76679800 \\ \mathrm{H} & -1.65568200 & -4.66319900 & -3.20299900 \\ \mathrm{H} & -0.10359900 & -0.98840100 & 5.33410600 \\ \mathrm{H} & 0.20949200 & -1.22393300 & 0.46743300 \\ \mathrm{H} & -2.72320500 & -0.59783700 & -2.26721700 \\ \mathrm{H} & 2.77226700 & -0.49889600 & 2.20062000 \\ \mathrm{H} & -0.58708200 & -6.08333700 & 0.04020800 \\ \mathrm{H} & -0.12778000 & -3.83967500 & -4.96407200 \\ \mathrm{H} & 0.13589700 & -3.45486400 & 5.16700500 \\ \mathrm{H} & 0.88285700 & -4.93923500 & -1.59012300 \\ \mathrm{H} & 0.24655600 & -1.40004500 & -5.25062300 \\ \mathrm{H} & 1.53628600 & -4.44999400 & 3.38805100 \\ \mathrm{H} & 3.58030900 & 0.49265800 & -4.60052200 \\ \mathrm{H} & -0.74958100 & 5.08877300 & -3.09624200 \\ \mathrm{H} & -4.99941100 & 4.97569700 & 0.75540100 \\ \mathrm{H} & 5.71353700 & -4.28523600 & -1.93592100 \\ \mathrm{H} & 2.07515200 & 3.48339600 & -1.39418400 \\ \mathrm{H} & -1.97479600 & 3.62228800 & 1.04124000 \\ \mathrm{H} & -5.63254600 & 0.59867800 & 2.15933300 \\ \mathrm{H} & 5.84635500 & 0.36481200 & -2.14430000 \\ \mathrm{H} & -2.13564500 & -2.80152200 & 2.93667500 \\ \mathrm{H} & -3.07270500 & -4.37494100 & -1.53949600 \\ \mathrm{H} & 0.48788800 & 1.15491300 & 4.69899700 \\ \mathrm{H} & 1.82782400 & -3.13408400 & -2.46436900 \\ \mathrm{H} & -0.32082900 & 0.80387300 & -4.80359800 \\ \mathrm{H} & 2.92776700 & -4.32000500 & 1.67148500 \\ \mathrm{H} & 3.53465900 & 3.32761700 & 3.31733100 \\ \mathrm{H} & -5.27728500 & 1.73164100 & 3.50866800 \\ \mathrm{H} & -4.46811800 & 3.19808400 & 3.67178700 \\ \mathrm{H} & & 3.24585100 & -3.83578400 \\ & 3.47502300 & 1.63604000 & -3.64686100\end{array}$

4.2. Optimized geometry of discrete helical decaradical derived from $\mathbf{2} \mathbf{b}$.

$\begin{array}{llll}\mathrm{C} & 6.80786800 & 2.39812400 & -2.73665700 \\ \mathrm{C} & 8.12848100 & 1.93347800 & -2.93515000\end{array}$




\begin{tabular}{|c|c|c|c|}
\hline $\mathrm{C}$ & 8.96124600 & 2.67145000 & -3.80589800 \\
\hline $\mathrm{C}$ & 8.48904900 & 3.80622200 & -4.46071600 \\
\hline $\mathrm{C}$ & 7.17491700 & 4.24319800 & -4.26051000 \\
\hline $\mathrm{C}$ & 6.33984900 & 3.53441600 & -3.39024700 \\
\hline $\mathrm{C}$ & 8.60157300 & 0.72392400 & -2.25960700 \\
\hline $\mathrm{C}$ & 7.66291900 & -0.38288500 & -2.08759300 \\
\hline $\mathrm{C}$ & 7.63264800 & -1.13446900 & -0.89682000 \\
\hline $\mathrm{C}$ & 6.67380900 & -2.13418500 & -0.67175900 \\
\hline $\mathrm{C}$ & 5.77312000 & -2.45124300 & -1.71040000 \\
\hline $\mathrm{C}$ & 5.79516000 & -1.72510200 & -2.90132800 \\
\hline $\mathrm{C}$ & 6.70993300 & -0.69264900 & -3.08660200 \\
\hline $\mathrm{C}$ & 6.48323400 & -2.71088700 & 0.67209200 \\
\hline $\mathrm{C}$ & 6.24522400 & -4.14340400 & 0.78667400 \\
\hline $\mathrm{C}$ & 5.39603400 & -4.70556900 & 1.77107300 \\
\hline $\mathrm{C}$ & 5.19195000 & -6.08033300 & 1.84638300 \\
\hline $\mathrm{C}$ & 5.81030000 & -6.94291500 & 0.93531700 \\
\hline $\mathrm{C}$ & 6.63099400 & -6.40680100 & -0.06346000 \\
\hline $\mathrm{C}$ & 6.84261000 & -5.03412200 & -0.13903600 \\
\hline $\mathrm{C}$ & 6.33454300 & -1.79944900 & 1.79190200 \\
\hline $\mathrm{C}$ & 6.42972300 & -2.19926700 & 3.15199900 \\
\hline $\mathrm{C}$ & 6.10235100 & -1.30846500 & 4.17325800 \\
\hline $\mathrm{C}$ & 5.65358900 & -0.01741900 & 3.89627700 \\
\hline $\mathrm{C}$ & 5.58218400 & 0.44305400 & 2.55388400 \\
\hline $\mathrm{C}$ & 5.99340200 & -0.44997500 & 1.54926700 \\
\hline $\mathrm{C}$ & 5.05602700 & 1.75897100 & 2.21014600 \\
\hline $\mathrm{C}$ & 5.14843100 & 2.84367100 & 3.19819300 \\
\hline $\mathrm{C}$ & 6.29874100 & 2.98717500 & 4.00549800 \\
\hline $\mathrm{C}$ & 6.40824000 & 4.02362800 & 4.92915500 \\
\hline $\mathrm{C}$ & 5.37227400 & 4.95156700 & 5.07409400 \\
\hline $\mathrm{C}$ & 4.22227000 & 4.82375400 & 4.28860200 \\
\hline $\mathrm{C}$ & 4.10734100 & 3.78349100 & 3.36916100 \\
\hline $\mathrm{C}$ & 4.44384700 & 2.02467500 & 0.90966600 \\
\hline $\mathrm{C}$ & 3.88299100 & 0.99768800 & 0.11367100 \\
\hline $\mathrm{C}$ & 3.32031200 & 1.21941800 & -1.16209900 \\
\hline $\mathrm{C}$ & 3.27672200 & 2.56471300 & -1.62118500 \\
\hline $\mathrm{C}$ & 3.81423900 & 3.59401000 & -0.85511000 \\
\hline $\mathrm{C}$ & 4.40533700 & 3.34202000 & 0.38008600 \\
\hline $\mathrm{C}$ & 2.82720400 & 0.13486700 & -1.99987900 \\
\hline $\mathrm{C}$ & 2.75333700 & 0.35698100 & -3.45824400 \\
\hline $\mathrm{C}$ & 3.81586100 & 0.96779300 & -4.15472500 \\
\hline $\mathrm{C}$ & 3.75764200 & 1.16267600 & -5.53276400 \\
\hline $\mathrm{C}$ & 2.63240500 & 0.75240100 & -6.25506500 \\
\hline $\mathrm{C}$ & 1.56567000 & 0.14908800 & -5.58110800 \\
\hline $\mathrm{C}$ & 1.62413400 & -0.04415600 & -4.20181600 \\
\hline $\mathrm{C}$ & 2.38707500 & -1.15680700 & -1.49137000 \\
\hline $\mathrm{C}$ & 1.91176100 & -1.33671400 & -0.17503200 \\
\hline $\mathrm{C}$ & 1.36823700 & -2.55510100 & 0.29409500 \\
\hline $\mathrm{C}$ & 1.35215400 & -3.64741700 & -0.61593700 \\
\hline $\mathrm{C}$ & 1.87199600 & -3.51233100 & -1.8992990 \\
\hline $\mathrm{C}$ & 2.38118200 & -2.29647300 & -2.3416630 \\
\hline
\end{tabular}




\begin{tabular}{|c|c|c|c|}
\hline $\mathrm{C}$ & 0.82359200 & -2.70381200 & 1.63640000 \\
\hline $\mathrm{C}$ & 0.71092500 & -4.05940000 & 2.20926900 \\
\hline $\mathrm{C}$ & -0.43994200 & -4.45033600 & 2.92748700 \\
\hline $\mathrm{C}$ & -0.54564300 & -5.72354300 & 3.48326600 \\
\hline $\mathrm{C}$ & 0.48794500 & -6.65123600 & 3.32329600 \\
\hline $\mathrm{C}$ & 1.63074100 & -6.28628500 & 2.60541000 \\
\hline $\mathrm{C}$ & 1.74585100 & -5.00837500 & 2.06213900 \\
\hline $\mathrm{C}$ & 0.36300400 & -1.57856200 & 2.44284900 \\
\hline $\mathrm{C}$ & 0.31719700 & -1.68243400 & 3.85943500 \\
\hline $\mathrm{C}$ & -0.15468700 & -0.62957100 & 4.63621500 \\
\hline $\mathrm{C}$ & -0.56018200 & 0.56552200 & 4.05173900 \\
\hline $\mathrm{C}$ & -0.49186700 & 0.74505500 & 2.64425300 \\
\hline $\mathrm{C}$ & -0.05515100 & -0.35398000 & 1.87503700 \\
\hline $\mathrm{C}$ & -0.82318100 & 2.03968100 & 2.05662600 \\
\hline $\mathrm{C}$ & -0.63762000 & 3.23347300 & 2.90642000 \\
\hline $\mathrm{C}$ & 0.50957700 & 3.36530500 & 3.71812600 \\
\hline $\mathrm{C}$ & 0.69500900 & 4.48241000 & 4.52934500 \\
\hline $\mathrm{C}$ & -0.25610500 & 5.50734900 & 4.54510500 \\
\hline $\mathrm{C}$ & -1.39711500 & 5.39636000 & 3.74479300 \\
\hline $\mathrm{C}$ & -1.58958000 & 4.27378900 & 2.94130100 \\
\hline $\mathrm{C}$ & -1.29194600 & 2.21689200 & 0.69228700 \\
\hline $\mathrm{C}$ & -1.87264500 & 1.16533400 & -0.05430600 \\
\hline $\mathrm{C}$ & -2.35807900 & 1.32318500 & -1.37156400 \\
\hline $\mathrm{C}$ & -2.27294200 & 2.62602000 & -1.93725900 \\
\hline $\mathrm{C}$ & -1.68709300 & 3.67211200 & -1.23291300 \\
\hline $\mathrm{C}$ & -1.18626600 & 3.48229500 & 0.05062900 \\
\hline $\mathrm{C}$ & -2.90995400 & 0.22194400 & -2.14690000 \\
\hline $\mathrm{C}$ & -2.93039300 & 0.34966600 & -3.61878500 \\
\hline $\mathrm{C}$ & -1.81753100 & 0.84076000 & -4.33246800 \\
\hline $\mathrm{C}$ & -1.85835400 & 0.97843200 & -5.71930600 \\
\hline $\mathrm{C}$ & -3.00767000 & 0.62272600 & -6.43236900 \\
\hline $\mathrm{C}$ & -4.11766600 & 0.12616400 & -5.74173300 \\
\hline $\mathrm{C}$ & -4.07798000 & -0.00698900 & -4.35590900 \\
\hline $\mathrm{C}$ & -3.45222000 & -0.99756800 & -1.55915800 \\
\hline $\mathrm{C}$ & -3.94752900 & -1.05105600 & -0.23836100 \\
\hline $\mathrm{C}$ & -4.50356300 & -2.21496600 & 0.34151800 \\
\hline $\mathrm{C}$ & -4.57106700 & -3.37235000 & -0.47854400 \\
\hline $\mathrm{C}$ & -4.07233800 & -3.35215200 & -1.77826500 \\
\hline $\mathrm{C}$ & -3.51435100 & -2.19784800 & -2.31873700 \\
\hline $\mathrm{C}$ & -4.98687200 & -2.24744600 & $1.7213890 \mathrm{C}$ \\
\hline $\mathrm{C}$ & -5.01314200 & -3.53314800 & 2.43442900 \\
\hline $\mathrm{C}$ & -6.07967900 & -3.86207400 & 3.29975600 \\
\hline $\mathrm{C}$ & -6.12000800 & -5.08651100 & 3.96243800 \\
\hline $\mathrm{C}$ & -5.09623200 & -6.02162000 & 3.78040100 \\
\hline $\mathrm{C}$ & -4.02788400 & -5.71293200 & 2.93226000 \\
\hline $\mathrm{C}$ & -3.98271400 & -4.48617900 & 2.27394500 \\
\hline $\mathrm{C}$ & -5.41751700 & -1.04167600 & 2.41624400 \\
\hline $\mathrm{C}$ & -5.35642100 & -0.92099300 & 3.83134900 \\
\hline $\mathrm{C}$ & -5.72507300 & 0.27262800 & 4.45119200 \\
\hline $\mathrm{C}$ & -6.09323900 & 1.39398800 & 3.7100160 \\
\hline
\end{tabular}




\begin{tabular}{|c|c|c|c|}
\hline $\mathrm{C}$ & -6.11697600 & 1.34110200 & 2.28911800 \\
\hline $\mathrm{C}$ & -5.86199400 & 0.08206900 & 1.69746900 \\
\hline $\mathrm{C}$ & -6.30787100 & 2.50152400 & 1.44330000 \\
\hline $\mathrm{C}$ & -6.06205800 & 3.86608400 & 1.89091600 \\
\hline $\mathrm{C}$ & -5.15862500 & 4.18754800 & 2.93273100 \\
\hline $\mathrm{C}$ & -4.95524800 & 5.50691000 & 3.32790100 \\
\hline $\mathrm{C}$ & -5.62902500 & 6.55303800 & 2.68946900 \\
\hline $\mathrm{C}$ & -6.50398200 & 6.26078200 & 1.63693200 \\
\hline $\mathrm{C}$ & -6.71400500 & 4.94388600 & 1.24200700 \\
\hline $\mathrm{C}$ & -6.56495400 & 2.27767100 & 0.00563200 \\
\hline $\mathrm{C}$ & -7.58922600 & 1.42096100 & -0.42096800 \\
\hline $\mathrm{C}$ & -7.69854400 & 0.99829700 & -1.76054700 \\
\hline $\mathrm{C}$ & -6.74999500 & 1.49246200 & -2.68647800 \\
\hline $\mathrm{C}$ & -5.76299900 & 2.38822100 & -2.28569100 \\
\hline $\mathrm{C}$ & -5.66795500 & 2.79143100 & -0.95334200 \\
\hline $\mathrm{C}$ & -8.72025000 & 0.03602600 & -2.16842000 \\
\hline $\mathrm{C}$ & -8.35616900 & -0.98971000 & -3.14681300 \\
\hline $\mathrm{C}$ & -7.06849900 & -1.57365500 & -3.13132100 \\
\hline $\mathrm{C}$ & -6.70379000 & -2.53462700 & -4.06983900 \\
\hline $\mathrm{C}$ & -7.61225400 & -2.94417400 & -5.05175200 \\
\hline $\mathrm{C}$ & -8.89539400 & -2.38637300 & -5.07668600 \\
\hline $\mathrm{C}$ & -9.26433700 & -1.42685500 & -4.13728700 \\
\hline $\mathrm{C}$ & -10.05407200 & 0.08164900 & -1.59431600 \\
\hline $\mathrm{C}$ & -10.59745000 & 1.29025900 & -1.0892040 \\
\hline $\mathrm{C}$ & -11.87121200 & 1.33228500 & -0.53336000 \\
\hline $\mathrm{C}$ & -12.65152400 & 0.17272600 & -0.45883500 \\
\hline $\mathrm{C}$ & -12.13638900 & -1.03194900 & -0.9510770 \\
\hline $\mathrm{C}$ & -10.86376100 & -1.07954000 & -1.5097270 \\
\hline $\mathrm{C}$ & 9.95684000 & 0.63764500 & -1.74417200 \\
\hline $\mathrm{C}$ & 10.60128500 & -0.61369100 & -1.57034300 \\
\hline $\mathrm{C}$ & 11.89689300 & -0.69537100 & -1.0722870 \\
\hline $\mathrm{C}$ & 12.59938300 & 0.46519500 & -0.7279600 \\
\hline $\mathrm{C}$ & 11.98337200 & 1.71150400 & -0.8898880 \\
\hline $\mathrm{C}$ & 10.68832000 & 1.79935000 & -1.38873200 \\
\hline $\mathrm{H}$ & 12.36667100 & -1.66932800 & -0.96004100 \\
\hline $\mathrm{H}$ & -12.26295800 & 2.27648500 & -0.1633520 \\
\hline $\mathrm{H}$ & -1.94277400 & 0.19334800 & 0.40502100 \\
\hline $\mathrm{H}$ & -8.26955700 & 1.00966700 & 0.31736500 \\
\hline $\mathrm{H}$ & 10.07293200 & -1.51879000 & -1.8509770 \\
\hline $\mathrm{H}$ & 3.91132500 & -0.01278800 & 0.4882250 \\
\hline $\mathrm{H}$ & -0.70133200 & 4.30400200 & 0.5631790 \\
\hline $\mathrm{H}$ & -4.86051500 & 3.44294100 & -0.6343780 \\
\hline $\mathrm{H}$ & 13.61158700 & 0.39929900 & -0.3381660 \\
\hline $\mathrm{H}$ & 4.85609500 & 4.15498400 & 0.9369010 \\
\hline $\mathrm{H}$ & -1.61372400 & 4.65312300 & -1.6956240 \\
\hline $\mathrm{H}$ & -5.03892600 & 2.74740100 & -3.0105870 \\
\hline $\mathrm{H}$ & 12.51335700 & 2.61998800 & -0.6146500 \\
\hline $\mathrm{H}$ & 3.78262100 & 4.61306500 & -1.2323320 \\
\hline $\mathrm{H}$ & 2.81455000 & 2.78774500 & -2.5756910 \\
\hline $\mathrm{H}$ & -2.67038000 & 2.80543000 & -2.9287050 \\
\hline
\end{tabular}




$\begin{array}{lrrr}\mathrm{H} & -6.80148100 & 1.16678600 & -3.71991800 \\ \mathrm{H} & 10.21340200 & 2.76963300 & -1.48847100 \\ \mathrm{H} & 1.94201200 & -0.49560400 & 0.49833700 \\ \mathrm{H} & -3.91217300 & -0.15250200 & 0.35540300 \\ \mathrm{H} & -10.00795700 & 2.19851300 & -1.15732600 \\ \mathrm{H} & 8.31666600 & -0.87582700 & -0.09553300 \\ \mathrm{H} & 2.77785300 & -2.21305500 & -3.34618200 \\ \mathrm{H} & -3.11561400 & -2.21230600 & -3.32640100 \\ \mathrm{H} & -10.46672800 & -2.02344600 & -1.86806300 \\ \mathrm{H} & 6.69986000 & -0.11440400 & -4.00444700 \\ \mathrm{H} & 0.91445000 & -4.59050300 & -0.31213800 \\ \mathrm{H} & -5.02549700 & -4.27617600 & -0.08979500 \\ \mathrm{H} & -13.64632200 & 0.20726800 & -0.02289500 \\ \mathrm{H} & 5.01476100 & -3.20952000 & -1.54527500 \\ \mathrm{H} & -0.93122400 & 1.37205500 & 4.67338000 \\ \mathrm{H} & -6.36514500 & 2.31240800 & 4.21786400 \\ \mathrm{H} & 5.33755000 & 0.63370300 & 4.70381600 \\ \mathrm{H} & -0.02377500 & -0.24738600 & 0.80285000 \\ \mathrm{H} & -5.96790400 & -0.01312100 & 0.62935600 \\ \mathrm{H} & 5.99907200 & -0.09554600 & 0.53175200 \\ \mathrm{H} & -0.19836800 & -0.73946900 & 5.71683300 \\ \mathrm{H} & -5.69959800 & 0.33827000 & 5.53611200 \\ \mathrm{H} & 6.17284700 & -1.63660300 & 5.20733700 \\ \mathrm{H} & 0.66420600 & -2.58987900 & 4.33928100 \\ \mathrm{H} & -5.00254200 & -1.75555300 & 4.42614900 \\ \mathrm{H} & 6.75923200 & -3.20373800 & 3.39348900 \\ \mathrm{H} & 1.86471600 & -4.36640700 & -2.57181600 \\ \mathrm{H} & -4.12330900 & -4.25443700 & -2.38247800 \\ \mathrm{H} & -4.58967000 & 3.39652200 & 3.40758800 \\ \mathrm{H} & -12.72763500 & -1.94216500 & -0.88861400 \\ \mathrm{H} & 5.06706200 & -1.93938100 & -3.67780800 \\ \mathrm{H} & -1.25576500 & -3.74436200 & 3.04432700 \\ \mathrm{H} & -6.88554300 & -3.14667400 & 3.43147100 \\ \mathrm{H} & 4.87100900 & -4.05172800 & 2.45822900 \\ \mathrm{H} & -1.44207800 & -5.98840300 & 4.03573700 \\ \mathrm{H} & -6.95965700 & -5.31706000 & 4.61326500 \\ \mathrm{H} & 4.53509600 & -6.47508100 & 2.61604400 \\ \mathrm{H} & 0.40384100 & -7.64639100 & 3.75219600 \\ \mathrm{H} & -5.13159200 & -6.97996500 & 4.29177900 \\ \mathrm{H} & 5.64912200 & -8.01580700 & 0.99730800 \\ \mathrm{H} & 2.43915200 & -6.99858900 & 2.46689400 \\ \mathrm{H} & -3.22190900 & -6.42517600 & 2.78319900 \\ \mathrm{H} & 7.11396200 & -7.06392300 & -0.78230500 \\ \mathrm{H} & -3.141442000 & -4.73394300 & 1.52188300 \\ \mathrm{H} & -4.25226600 & 1.62958600 \\ \mathrm{H} & & 2.28066800 & 3.88352700 \\ \mathrm{H} & 5.55019100 & 5.14242600 \\ \mathrm{H} & 5.71559100 & 4.13055000\end{array}$




$\begin{array}{crrr}\mathrm{H} & 7.31054400 & 4.11547600 & 5.52844600 \\ \mathrm{H} & -0.11077300 & 6.38128200 & 5.17485600 \\ \mathrm{H} & -5.46878900 & 7.58164600 & 3.00137700 \\ \mathrm{H} & 5.46060300 & 5.76527900 & 5.78907500 \\ \mathrm{H} & -2.14513700 & 6.18398200 & 3.74434700 \\ \mathrm{H} & -7.02934600 & 7.06404600 & 1.12648900 \\ \mathrm{H} & 3.40788400 & 5.53528500 & 4.38993700 \\ \mathrm{H} & -2.48753300 & 4.19157800 & 2.33801400 \\ \mathrm{H} & -7.40082000 & 4.72407800 & 0.43054100 \\ \mathrm{H} & 3.20299200 & 3.68699700 & 2.77709300 \\ \mathrm{H} & -0.91771800 & 1.11306500 & -3.79069500 \\ \mathrm{H} & -6.36019900 & -1.28124800 & -2.36202900 \\ \mathrm{H} & 9.97709700 & 2.32779800 & -3.97494800 \\ \mathrm{H} & 4.69628400 & 1.27529400 & -3.60587600 \\ \mathrm{H} & -0.98576000 & 1.36188300 & -6.24030500 \\ \mathrm{H} & -5.70822100 & -2.96518200 & -4.02099600 \\ \mathrm{H} & 9.14545800 & 4.34709600 & -5.13789000 \\ \mathrm{H} & 4.59733200 & 1.63107600 & -6.04023300 \\ \mathrm{H} & 2.58733100 & 0.90009900 & -7.33100200 \\ \mathrm{H} & -3.03736400 & 0.73223100 & -7.51334800 \\ \mathrm{H} & -7.32602400 & -3.69246100 & -5.78617100 \\ \mathrm{H} & 6.80843400 & 5.12885500 & -4.77291200 \\ \mathrm{H} & 0.68023200 & -0.16762400 & -6.12406900 \\ \mathrm{H} & -5.02099400 & -0.15435100 & -6.27773800 \\ \mathrm{H} & -9.60805500 & -2.69360300 & -5.83806600 \\ \mathrm{H} & 5.32234000 & 3.86525800 & -3.20543800 \\ \mathrm{H} & 0.79011700 & -0.50950100 & -3.68630200 \\ \mathrm{H} & -4.94676900 & -0.37788200 & -3.82856700 \\ \mathrm{H} & -10.25600900 & -0.98618000 & -4.16888100 \\ \mathrm{H} & 6.15630100 & 1.87116600 & -2.04616900\end{array}$

4.3.Calculated energetic differences in the helical decaradical derived from $\mathbf{2} \mathbf{b}$.

Molecular units presenting ten magnetic centres have at least six solutions with different multiplicity, ranging from $S=5$ (undecet) to $S=0$ (singlet). Within the mapping approach, one can approximate the pure spin states through broken symmetry solutions to extract magnetic exchange interactions, provided a correct spin projector is defined. Here, however, we use the broken symmetry solutions to approximate the energetic difference between the several states with different multiplicity. The high-spin state is well described with a single determinant of the type $|\alpha \alpha \alpha \alpha \alpha \alpha \alpha \alpha \alpha \alpha\rangle$, which, by convenience will be represented as $|10 \alpha\rangle$. Similarly, the other five low-spin states can be approximated by single determinants of the type $|9 \alpha 1 \beta\rangle,|8 \alpha 2 \beta\rangle,|7 \alpha 3 \beta\rangle,|6 \alpha 4 \beta\rangle$ and $|5 \alpha 5 \beta\rangle$, respectively. For each multiplicity in the low-spin cases, there are several broken symmetry solutions with similar energy, depending on where the beta spin 
density is located. In a non-systematic manner we investigated some of the different solutions, and no relevant change was observed. Table S. I. 5 reports the energetic differences among the high-spin solution and the most stable low-spin solution found in each case. It clearly illustrates that also in the molecular case, the high spin is the ground state and it is well above the most stable antiferromagnetic solution.

Table S. I. 5. Absolute energies (a.u.) and the corresponding energy difference $\left(\mathrm{cm}^{-1}\right)$ referred to the most stable state (high-spin) as calculated in the optimized geometry of the polymer $\mathbf{2 b}$ derived decaradical. Negative values for $\Delta \mathrm{E}$ imply a high-spin ground state.

\begin{tabular}{cc|cc}
\hline \multicolumn{4}{c}{ 2b derived } \\
\hline Solution & Absolute energy (a.u.) & $\Delta \mathrm{E}\left(\mathrm{cm}^{-1}\right)$ \\
\hline$|10 \alpha\rangle$ & -5240.53686416 & $|10 \alpha\rangle-|9 \alpha 1 \beta\rangle$ & -322 \\
$|9 \alpha 1 \beta\rangle$ & -5240.53539632 & $|10 \alpha\rangle-|8 \alpha 2 \beta\rangle$ & -602 \\
$|8 \alpha 2 \beta\rangle$ & -5240.53411933 & $|10 \alpha\rangle-|7 \alpha 3 \beta\rangle$ & -1112 \\
$|7 \alpha 3 \beta\rangle$ & -5240.53179894 & $|10 \alpha\rangle-|6 \alpha 4 \beta\rangle$ & -1077 \\
$|6 \alpha 4 \beta\rangle$ & -5240.53195893 & $|10 \alpha\rangle-|5 \alpha 5 \beta\rangle$ & -1104 \\
$|5 \alpha 5 \beta\rangle$ & -5240.53183543 &
\end{tabular}




\section{Singly occupied molecular orbitals (SOMO) and spin density for the helical decaradical derived from $2 b$}

Analysis of the singly occupied molecular orbitals and electron density for this decaradical presented in Figure S. I. 5 clearly show that, in spite of loosing planarity, the helical conformation introduces effective $\pi-\pi$ interactions favouring the high spin coupling so that the resulting ground state is ferromagnetic.

Figure S. I. 5 Contour plots of singly occupied molecular orbitals (SOMO) and spin density for the ferromagnetic (FM) solution corresponding to the helical decaradical derived from $2 \mathbf{b}$. Plots correspond to isovalues of 0.02 and 0.05 for molecular orbitals and spin density, respectively.

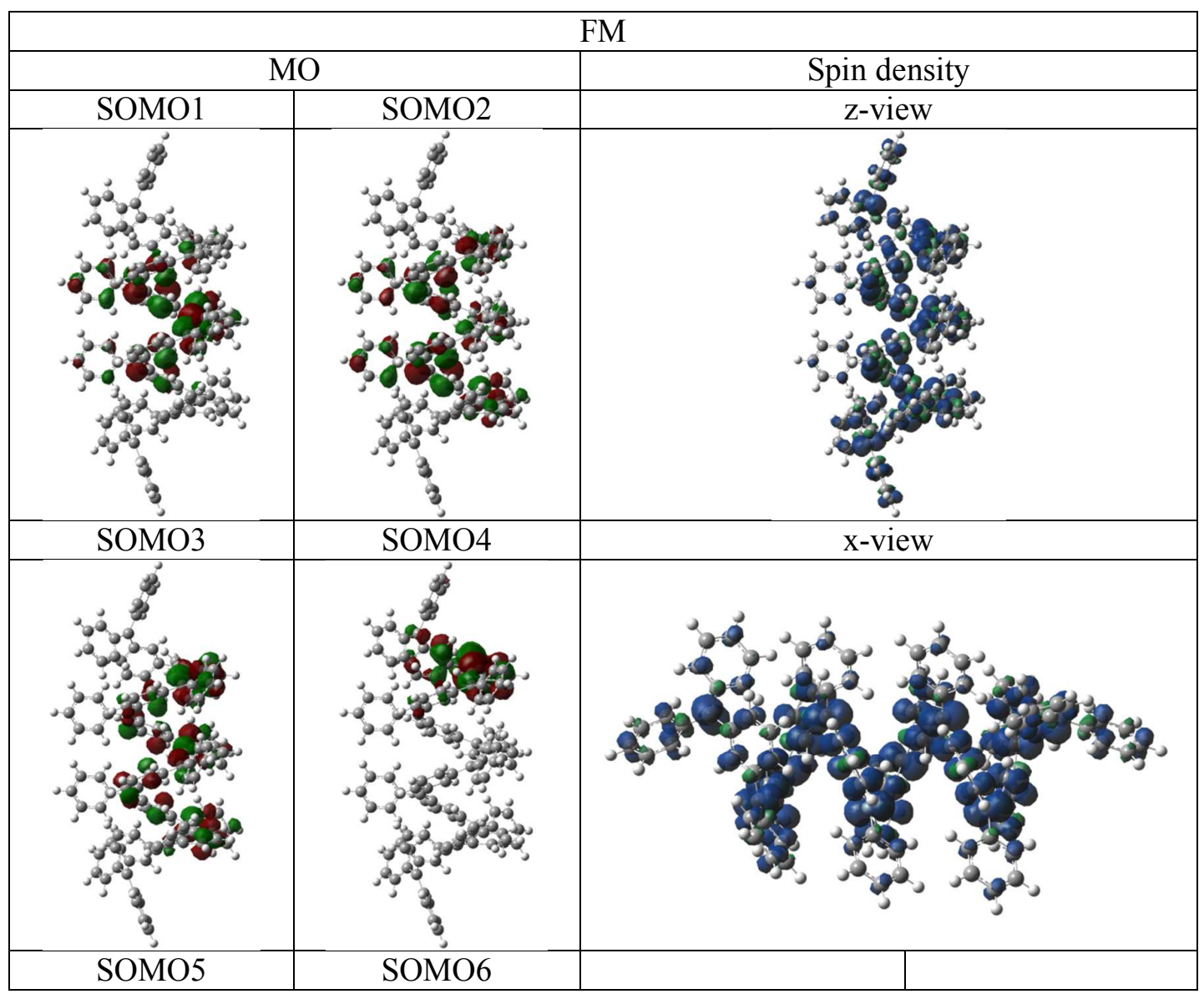


Supporting Information

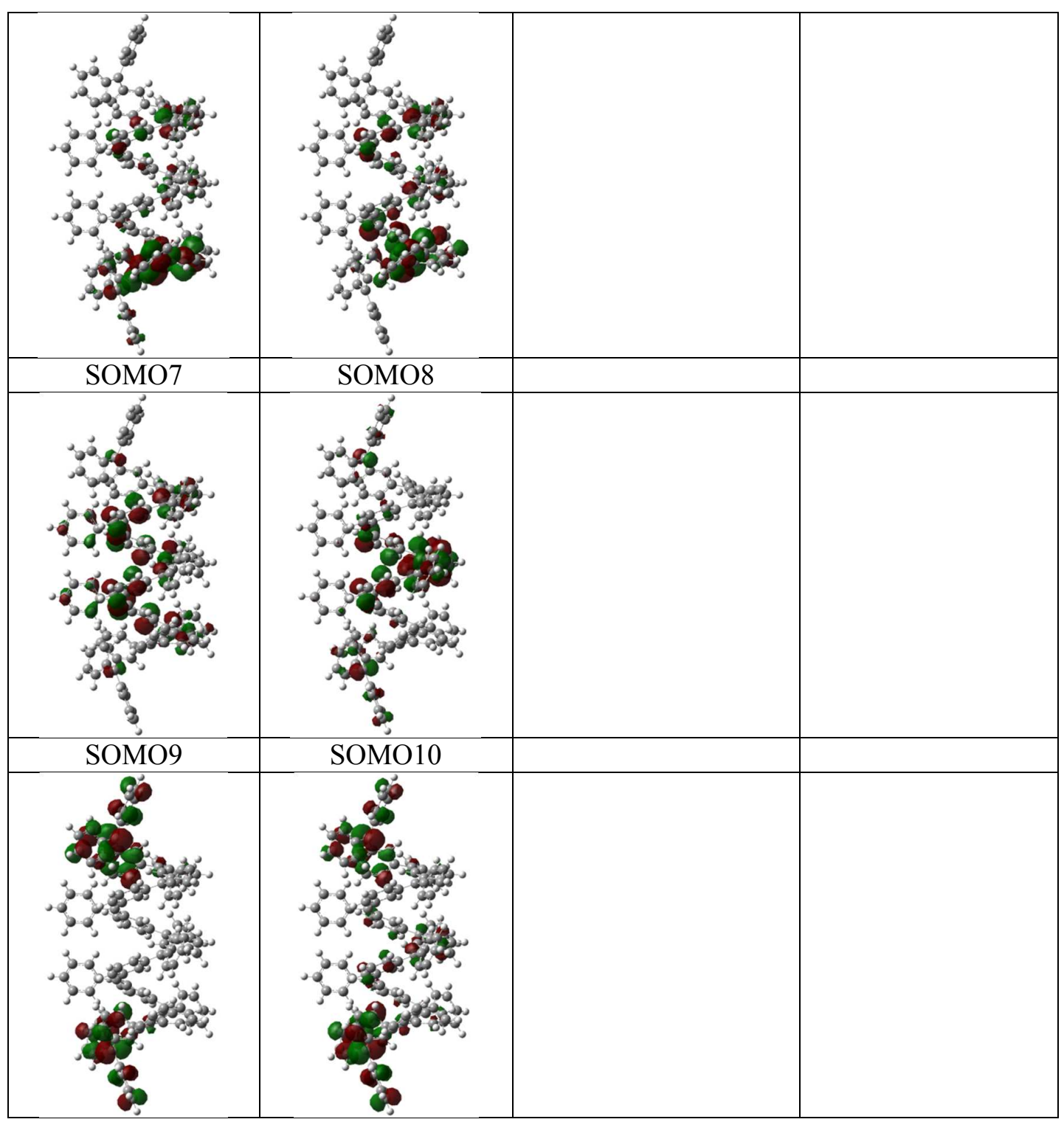




\section{References}

${ }^{1}$ Dovesi, R.; Orlando, R.; Civalleri, B. CRYSTAL: A Computational Tool for the Ab Initio Study of the Electronic Properties of Crystals. Z. Krist. 2005, 220, 571-573.

${ }^{2}$ Dovesi, R.; Saunders, V. R.; Roetti, C.; Orlando, R.; Zicovich-Wilson, C. M.; Pascale, F.; Civalleri, B.; Doll, K.; Harrison, N. M.; Bush, I. J.; et al. CRYSTAL09 User's Manual. University of Torino. Torino 2009.

${ }^{3}$ Heisenberg, W. Zur Theorie Des Ferromagnetismus. Zeitschrift für Phys. 1928, 49 (910), 619-636.

${ }^{4}$ Dirac, P. A. M. The Principles of Quantum Mechanics; Clarendon Press: Oxford, 1958.

5 Van Vleck, J. H. The Theory of Electric and Magnetic Susceptibilities; Oxford University Press: Oxford, 1932.

${ }^{6}$ Ising, E. Beitrag Zur Theorie Des Ferromagnetismus. Zeitschrift für Phys. 1925, 31 (1), 253-258. 